\title{
مقدمــــة
}

يعتبر التحكيم أحد أهم الوسائل لفض المنازعات التجارية نظراً لمزاياه المتمثلة في السرعة والمرونة في اختيار الخصوم للقانون الواجب التطبيق و المحكمين ووجود قو اعد تضمن بساطة الإجراءات ونهائية حكم التحكيم فضلاً عن تحييد دور القضاء في النظر في موضوع النزاع والسرية التي تكفل حماية سمعة الخصوم. ورغم هذه المزايا إلا أن نظام التحكيم السعودي ولاحتها التنفيذية قد سلبا التحكيم أهم مزاياه بسبب الثتمالهما على العوائق القانونية

أولاً : أن اعتماد وثيقة التحكيم من قبل الجهة القضائية المختصة يستغرق وقت طويل لأسباب قد تعود للخصوم مثل رفض أحد الخصوم تعيين محكمه أو عدم أتفاق المحكمين المختارين من قبل الخصوم للمحكم المرجح أو انسحاب أحد المحكمين قبل بدء إجراءات التحكيم أو عدم

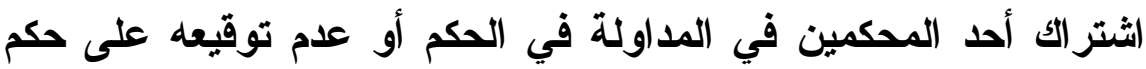
التحكيم.(') لذلك فإن الحاجة تبدو ظاهرة إلى معرفة الطرق التئ لدئ يمكن

* دكتوراه في القانون التجاري ، جامعة دندي ، بريطانيا ، ماجستير في القانون التجاري،

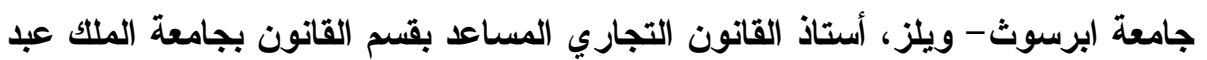

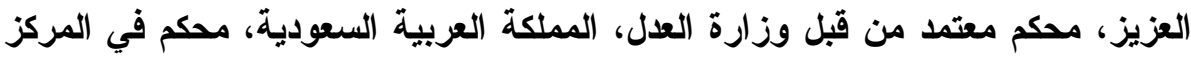

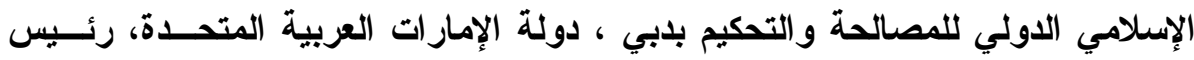

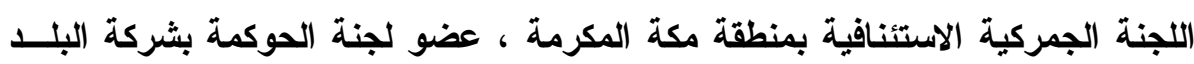
الأمين ، مكة المكرمة ، المملكة العربية السعودية. (1) المادتين (0) و (7) من نظام التحكيم. 
أتباعها لتسريع الوصول إلى حكم نهائي دون تسويف أو مماطلة من قبل الخصوم أو المحكمين

ثانياً : أن الخصوم لا يملكون الحق في اختيار قانون أجنبي أو مبادئ

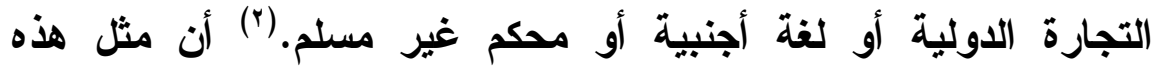
الخيارات قد تثصادم مع حكم المادة ( • ( ) من نظام التحكيم والتي تتطلب

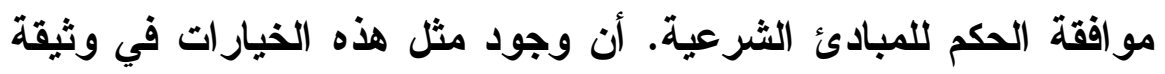
التحكيم من شأنه أن يعرقل اعتماد الوثيقة ويحول دون تنفيذ أحكام التحكيم كما أنه قد يحول دون تنفيذ المملكة لالتزاماتها في الاتفاقيات

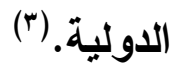

ثالثاً : أن تنفيذ حكم التحكيم مرتبط بعدم مخالفته للمبادئ الثرعية والنظامية

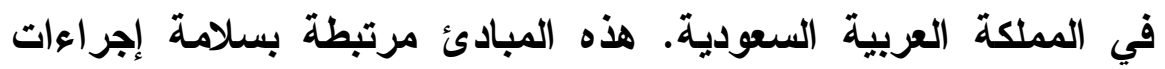

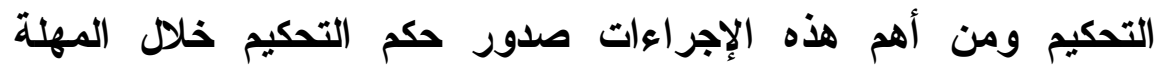
التظامية المحددة بتسعين يوماً من تاريخ اعتماد وثيقة التحكيم وقابلية

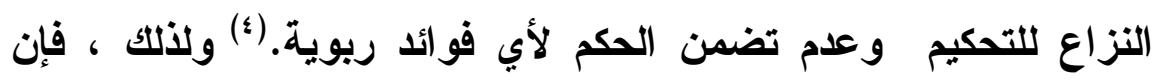
صدور حكم التحكيم بعد اتقضاء المهلة قد يؤدي إلى بطلان حكم التحكيم

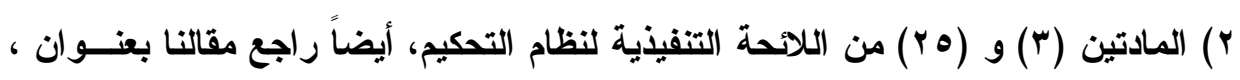

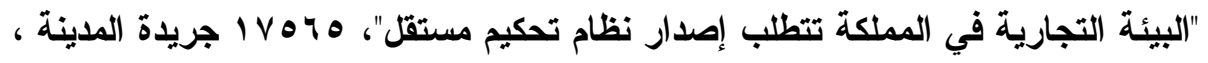

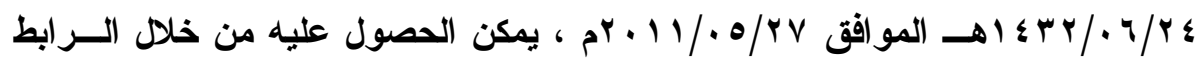
http://al-madina.com/node/306003

$$
\text { التالي: nen }
$$
r) ومن أهم هذه الاتفاقيات اتفاقية واشنطن ICSID واتفاقية نيويورك المتعلقة بتفيذ أحكام التحكيم الأجنبية والاتفاقيات الثنائية. عمر مشهور حديثة الجازي ، 9 9، ، ـ ـ 1 مجلة نقابة

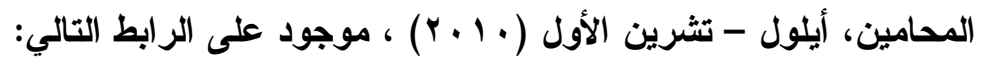
http://www.jcdr.com/pdf/3-ar.pdf צ) المادة (Y) من نظام التحكيم. 
وذات النتيجة سوف تحصل إذا تضمن الحكم فوائد أو تعويض عن الكسب

أن تسليط الضوء على أهم العوائق القانونية التي تواجه التحكيم في المملكة العربية السعودية مهمة لعدة اعتبار ات من أهمها التالي : أولاًا : أن نظام التحكيم ولانحته التتفيذية يخضعان حالياً للاراسة من قبل السلطة التظيمية ومن المتصور أن يصدر مشروع نظام جديا يتضمن إلغاء للنظام الحالي. ولذلك فإن استعراض الورقة للعوائق القانونية للتحكيم في المملكة من شأنه المساعدة في تلافي الخلل والقصور وتظوير النصوص النظامية بما يحقق الغاية التي وجد من أجلها التحكيم.

ثانياً : أن الدراسات القانونية المتعلقة بالتحكيم في المملكة تعتبر شحيحة ولم تحظ باهتمام الباحثين القانونيين،(•) لذا فإن هذه الاراسة قـ تفتح

ه) من ضمن الدراسات القلية في التحكيم السعودي مؤلف الدكتور محمد بن ناصر البجاد،

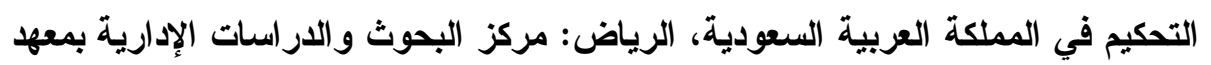

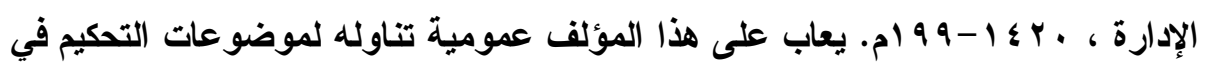
المملكة كما أن الدراسة غلب عليها الطابع الوصفي وافتقدت للمنهج النقدي - المقارن. فضلاً عن ذلك فإن المؤلف يعد قديم نسبياً إذ أن أخر نسخه منه صدرت عان عام قبل (11)

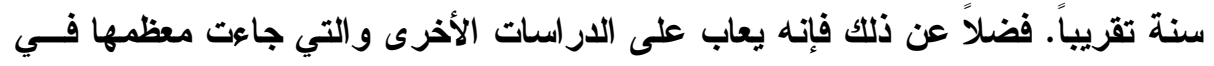

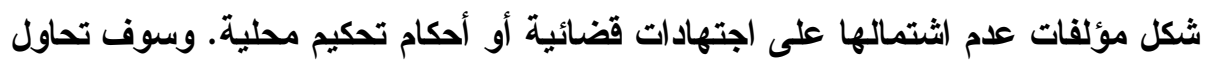

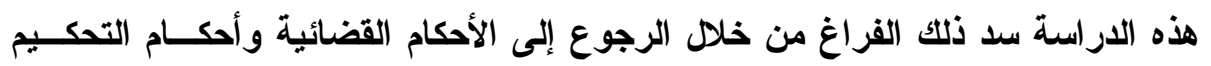
و التي لم يسبق نشرها. 
المجال للباحثين في بحث الإثكاليات التي يواجهها نظام التحكيم

$$
\text { السعودي. }
$$

ثالثاً : أن الورقة تعد مهمة للمحكمين وقضاة المحاكم وكذلك الخصوم لأهها توضتح الحالات التي قـ تعيق إجراعات التحكيم وإبطال اتفاق وحكم التحكيم لألك فإن نتائج الورقة قد تشاعد ذوي الشأن في معرفة الحالات والثغرات والدفوع والحلول التي قد تنشأ قبل وأثناء نظر النزاع من قبل هيئة التحكيم وبعد صدور الحكم الأمر الذي من شأنه تعزيز دور التحكيم في فض النزاع بشكل نهائي وذلك من خلال تفادي المخاطر التي يواجهها اتفاق وإجر اعات وحكم التحكيم.

رابعاً : أن العوائق القانونية المتجسدة في نظام التحكيم السعودي تعتبر خطيرة على مستقبل الاقتصاد المحلي ومصلحة بيئة الأعمال والاستثمار الأجنبي في المملكة مما قد يتسبب في التقليل من حجم الاستثمار ات الأجنبية في المملكة فضلاً عن أنها قد تثبط همة الخصوم وهجر التحكيم واللجوء إلى القضاء بالاً عن ذلك باعتباره صاحب الولاية العامة في نظر

$$
\text { النز اعات. }
$$

\section{منهجبية الورقة}

يتبع الباحث في هذه الورقة المنهج التحليلي والنقدي المقارن. يقوم الباحث بمقارنة نظام التحكيم ولاتحته التنفيذية بقوانين التحكيم في الدول العربية مع إعطاء أهمية خاصة لكلاً من قانون التحكيم المصري وقانون التحكيم الأردني. الهُف من التركيز على هذين القانونين يعزى للأسباب

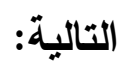

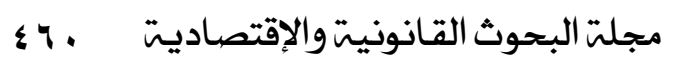


أولاً : أن القانون المصري والقانون الأردني قد تضمنا الكثير من الأحكام التي تعطي التحكيم الكثير من الفعالية والأهمية فيما يتعلق بالمرونة والسرعة

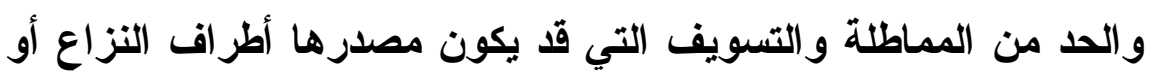
المحكمين.

ثانياً : أن القانون المصري والقانون الأردني قد استفادا من تطور فقه

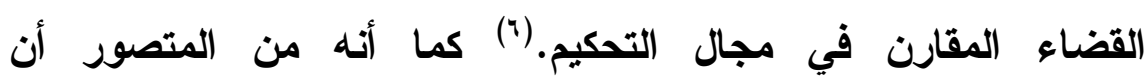
يساير مشروع نظام التحكيم الجديد في المملكة التطورات التشريعية في مجال التحكيم في كلاً من جمهورية مصر العربية والمملكة الأردنية الهاشمية.

مصادر الورقة

تعتمد الورقة على مصادر أولية تثمثل في تحليل ونقد النصوص القانونية لنظام التحكيم ولاتحته التنفيذية ومقارنة تلك النصوص بتلك الموجودة في كلاً من القانون المصري والقانون الأردني. كما أنه سوف يتم الرجوع إلى قوانين الدول الغربية والعربية التي تتبنى مواقف تخدم التحكيم وتحقق الغاية التي وجد من أجلها. أيضاً سوف يقوم الباحث بأخذ أراء شراح القانون المتجسدة في الكتب والمجلات العلمية المتخصصة. فضلاً عن الرجوع إلى الاجتهادات القضائية للاول العربية المتوفرة في إصدارات مجلة التحكيم اللبنانية.

7) عبد الستار الخويلاي ، "آليات الحد من المماطلة والتسويف في مجال التحكيم" ورقــة

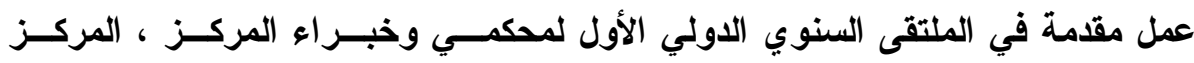

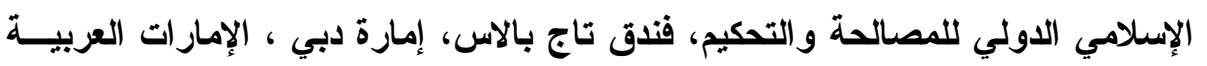

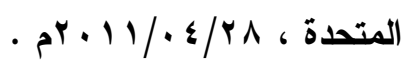




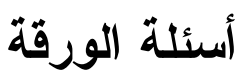

السؤال الجوهري الذي تطرحه هذه الورقة هو : ما هي أهم العوائق

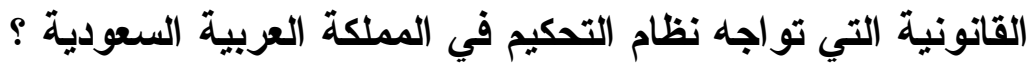

يتفرع عن هذا السؤال أربعة أسئلة هي كالتالي :

(1) ما هي الأسباب التي تؤدي إلى بطلان وثيقة التحكيم ؟

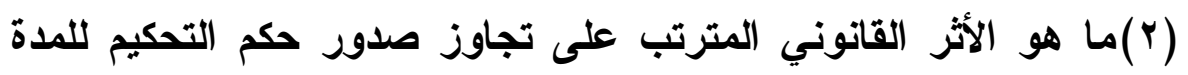

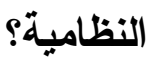

(r)ما هي المدة الزمنية التي يتطلبها النظام لإصدار أحكام تفسيرية أو

$$
\text { تصحيحية؟ }
$$

(§)ما هي المحكمة المختصة بدعوى بطلان أحكام التحكيم وهل قضى الصى مشروع النظام الجديد على العوائق الموجودة في نظام التحكيم

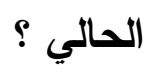

(•)ما هي أهم التظورات التي استحدثها مشروع النظام الجديد وهل تظلب

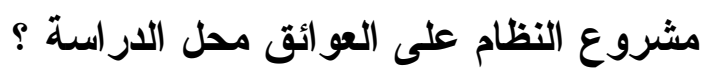

أهداف الورقة

تتلخص أهداف هذه الورقة في الآتي :

- تسليط الضوء على العوائق القانونية المتجسدة في نظام التحكيم

ولاحته التتفيذية والتي تحول دون تحقيق التحكيم لغاياته.

- معرفة توجه القضاء عند نظره الطعون ضد إجراءات وأحكام التحكيم

المحلية.

النظر في مدى نجاح مشروع النظام الجديد في التظلب على العوائق

التي تواجه التحكيم في المملكة. 
سوف تقسم الورقة إلى مبحثين رئيسين على النحو التالي :

المبحث الأول : يناقش صحة وثيقة التحكيم وينقم إلى فرعين هما:

أهية وثيقة التحكيم والأثر القانوني لتجاوز حكم التحكيم للمدة النظامية.

المبحث الثاني : يناقش المحكمة المختصة بنظر دعوى البطلان وينقسم إلى فرعين : إجراءات مدة رفع دعوى البطلان والمحكمة المختصة بالبطلان.

المبحث الثالث: يتعرض تقييم العوائق في ظل مشروع النظام الجديد وينقسم إلى فرعين هما : تقييم العوائق - محل الدارسة - في ظل مشروع

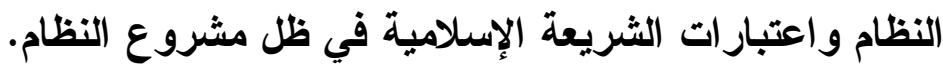




\section{المبحث الأول : صحة وثيقة التحكيم}

ورد لفظ وثيقة التحكيم في القانون السعودي ليدلل على أتفاق التحكيم الذي يجب أن يتضمن عناصر محددة هي : موضوع النزاع ، وأسماء الخصوم، وتوقيعاتهم، أو وكلاههم الرسميين المفوضين، و وأسماء المحكمين

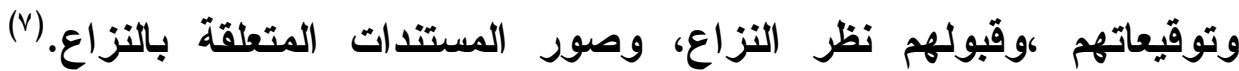
يناقش هذا المبحث الأثر المترتب على تخلف أحد تلك البيانات على صحة وثيقة التحكيم ومعرفة الأثز المترتب على تجاوز الحكم للمدة النظامية. ينقسم

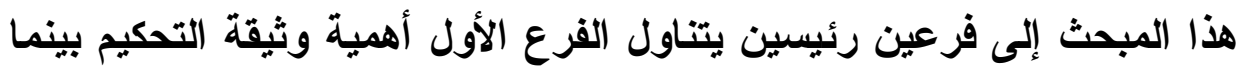
يتناول الفرع الثاني الأثر القانوني لتجاوز حمم المحكمين للمدة النظامية. الفرع الأول : أهمية وثيقة التحكيم تعتبر وثيقة التحكيم طبقاً لنظام التحكيم في غاية الأهمية للأسباب

أولاً : أنه بدون وجود واعتماد الوثيقة من قبل الجهة القضائية المختصة فإن

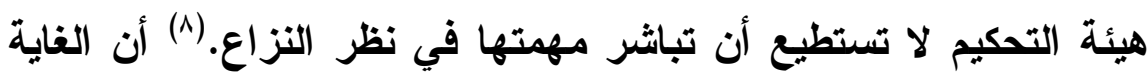

(المادة (0) من النظام. ويفضل إضافة إلى ذلك أن تتضمن الوثيقة تحديد أتعاب المحكمين

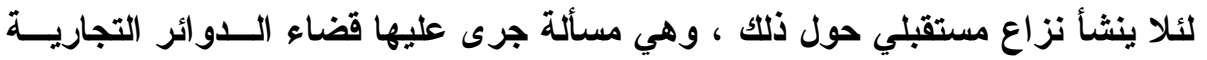

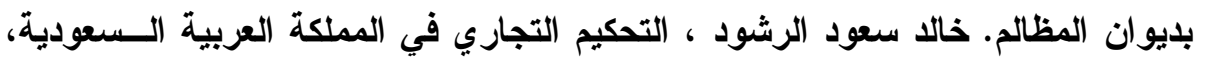

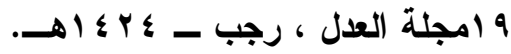

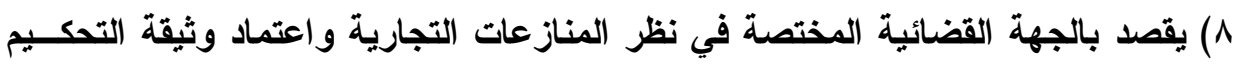

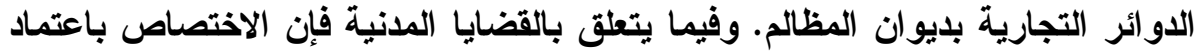

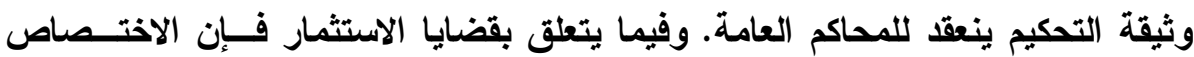

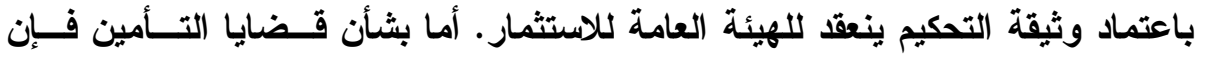

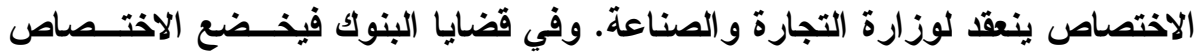

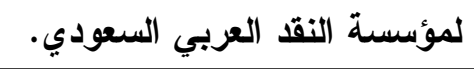


من اعتماد الوثيقة هو رغبة القضاء في فرض رقابة سابقة على إجراعات التحكيم بغرض التحقق من مطابقة الوثيقة للنظام العام ونظام

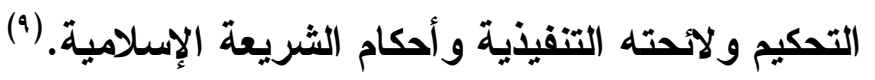

ثانياً : يجب أن تشتمل وثيقة التحكيم على بيانات محددة جاهت على سبيل الحصر في النظام كما وضحنا أنفاً. ولا يترتب على تخلف أحد البيانات

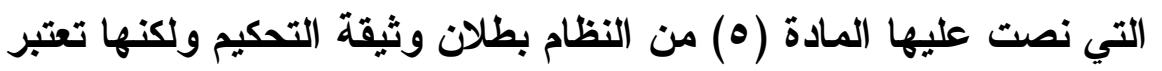
ناقصة مما يتطلب تصحيحها باستكمال البيان أو البيانات الناقصة "وهذا

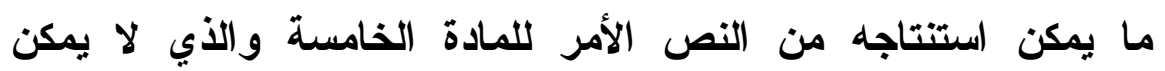

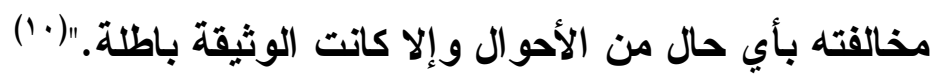

إن تخلف أحد تلك البيانات يترتب عليه تأخير اعتماد وثيقة التحكيم مما يؤدي إلى تعطيل البدء بإجراءات التحكيم ومن أمثلة ذلك تأخر أو عدم تعيين

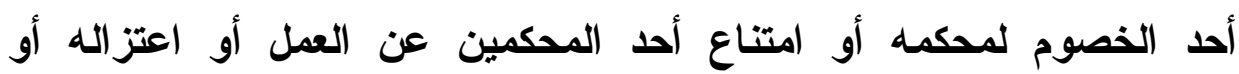
التسويف في تعيين المحكم المرجح. ('') ففي هذه الحالة يقوم القاضي بتحديا جلسة بناءً على طلب صاحب المصلحة من الخصوم و بحضور الخصم الآخر ليتم تعيين المحكم أو المحكمين ويكون قرار القاضي في هذا الشأن نهائياً طبقاً للمادة العاثرة من النظام. وما يعاب على نظام التحكيم ولائحته التنفيذية عدم

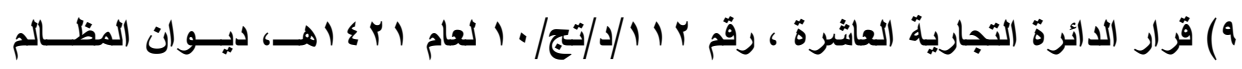
بمنطقة مكة المكرمة.

• 1) محمد بن ناصر البجاد ، التحكيم في المملكة العربية السعودية ، الريــاض، معهـــ

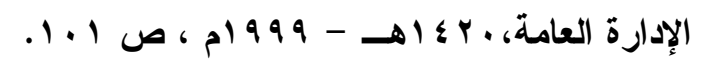

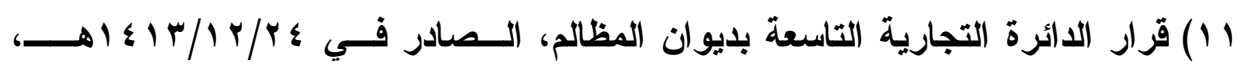

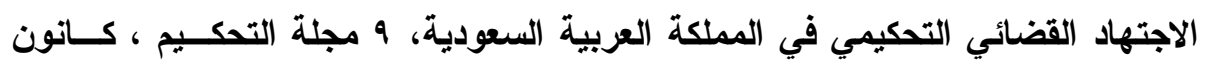

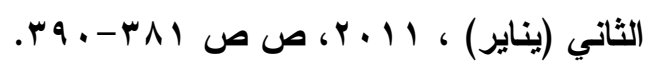


د. ر انايف بن سلطان الشريف

تضمنهما مدد معينة يتم من خلالها إلزام الخصوم بتعيين المحكمين مما يفتح المجال للخصوم لإتباع الأساليب التسويفية التي تحول دون السير في إجراءات التحكيم.(r) ومن بين الأسباب الأخرى التي يلجأ إليها الخصوم لتعطيل إجراءات التحكيم اختيار محكمين غير مؤهلين للاضطلاع بمهمة نظر النزاع مما يطيل أمد نظر الدعوى ولذلك فإن ثمة حاجة تظهر لتعديل المادة (•) من نظام التحكيم بحيث يقتصر تعيين المحكمين على القائمة الرسمية والتي يجب أن يشترك في إعدادها كل من وزارة العدل ووزارة التجارة والصناعة ورئاسة ديوان المظالم.(rا) ورغم ذلك فإن ثمة حالات أخرى - خلاف حالة تعيين المحكمين - يخضع فيها قرار اعتماد وثيقة التحكيم للطعن أمام هيئة التدقيق

r 1 ) طبقاً للمادة (1 1) من القانون النموذجي للتحكيم "إذا كان التحكيم بثلاثة محكمين ، ولم

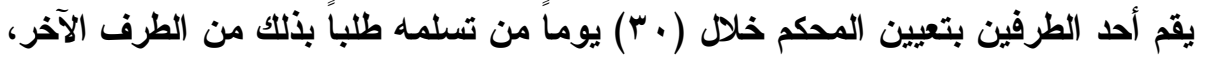

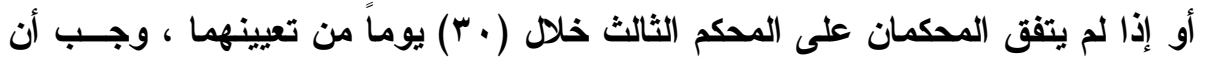
تقوم بتعيينه بناء على طلب أحد الطرفين المحكمة أو السلطة الأخرى المسماة في المادة

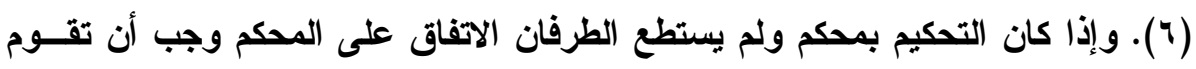
بتعيينه بناء على طلب أحد الطرفين المحكمة أو السلطة الأخرى المسماة في المادة (؟). في ذات المعنى أنظر المادة (11) من قانون التحكيم المصري.

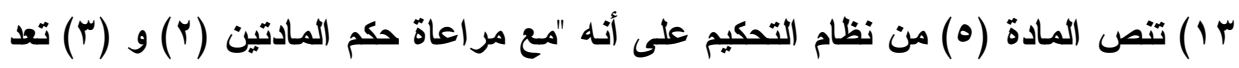

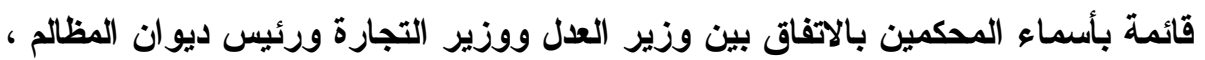

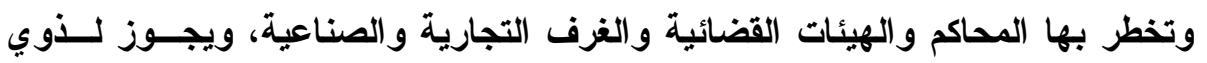

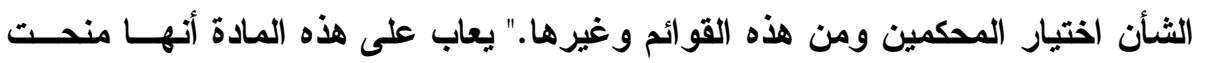

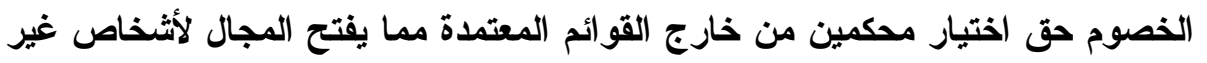

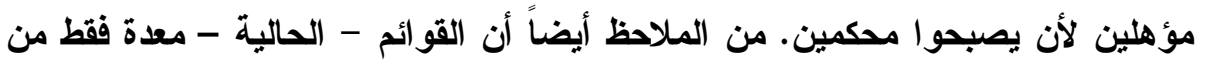

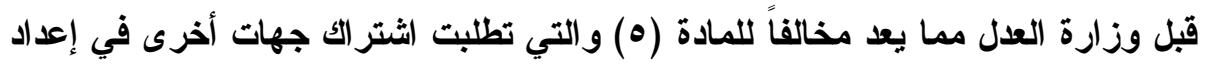

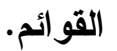


بمعنى آخر "يعتبر قرار اعتماد وثيقة التحكيم قراراً قضائياً ، يتم التظلم منه أمسام الجهة التي أصدرته ، كما يتم الطعن بالتمييز في القرار الصادر من تلك الجهة بخصوص هذا التظلم. ولا يمكن إجراء التحكيم بلون اتخاذ هذا الإجراء الأي تطلبه النظام. والأي يهدف إلى إسباغ نوع من الرقابة الرسمية على عملية التحكيم. هذه الرقابة التي بلورها تشبغ الشرعية القضائية على عملية التحكيم برمتها ، مما يؤكد الطبيعية القانونية للتحكيم بأنه قضاء. وبناء عليه لا يمكن وبأي حال من الأحوال اعتبار الطبيعة القانونية لهذا الإجراء مجرد تحقق من شخصية أطراف التحكيم عن طريق المصادقة على تواقيعهم ، أو أو أنها مجرد رقابة موضوعية على صحة اتفاق التحكيم تتم عن طريق توثثيه بشكل رسمي أمام الجهة المختصة بالفصل في النزاع."(؛) ومن ومن المسائل التي يجوز فيها لأحد الخصوم الاعتراض على اعتماد وثيقة التحكيم الآتي : عدم

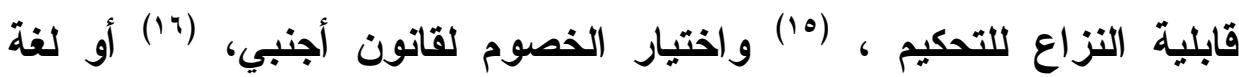
أجنبية ،(IV) أو ثبوت مصلحة لأحد المحكمين في النزاع أو عدم توفر الثروط الللزمة في المحكم .(^) ولذلك فإن المسائل التي يجوز فيها للخصوم التظلم على قرار اعتماد وثيقة التحكيم هي ذاتها المسائل التي تجيز للخصوم الاعتر اض على إجراءات أو حمم التحكيم أي تلك التي تخالف نظام التحكيم أو لاتحته التنفيذية. وقد أثثب الواقع العملي أن بيان "موضوع النزاع" يعتبر احد

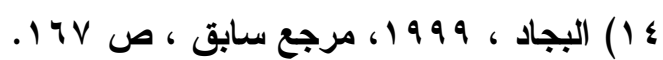

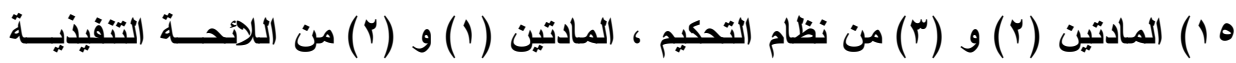
للنظام.

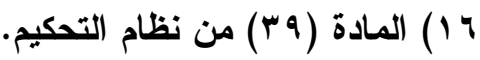

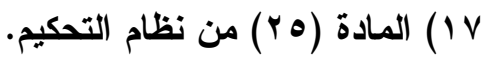

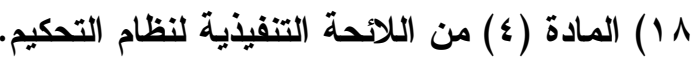


أهم البيانات الذي يثار حوله دائماً الجدل فيما بين الخصوم إذ أن كل طرف يعترض على طلبات خصمه ويحتدم الخلاف بين الخصوم أمسام المحكمة المختصة - الدائرة التجارية -عند نظرها اعتماد وثيقة التحكيم ويستطيع أي من الخصوم إطالة أمد النزاع من خلال الاعتراض على حكم الائرة باعتماد وثيقة التحكيم أمام هيئة التدقيق.(9) ولتفادي هذه المشكلة فإنها يقترح على هن الجهة القضائية المختصة تصميم نموذج موحد لوثيقة التحكيم يتضمن جميع الأحكام الآمرة التي لا يجوز للخصوم الاتفاق على مخالفتها مع إعطاء كل خصم الحق في طرح جميع طلباته مع الإشارة إلى أن طرح طلبات أي من الخصوم أو ذكر بعض الوقائع في الوثيقة لا يعتبر إقرار صادر من أي من الطرفين بصحة تلك الطلبات أو الوقائع.(r) كما أنه يقترح تعديل المادة (19) من النظام بحيث يكون الاعتراض على أحكام المحكمين أمام هيئة التدقيق وليس الدائرة التجارية أسوة بقرار ات اللجنة الطبية الشرعية. (rان) ثالثاً، أن تحديد أجل لصدور حكم التحكيم في وثيقة التحكيم يعتبر مهماً لأن التحكيم وجد بغرض إيجاد حل سريع وناجع للمنازعات التجارية ومن ثم

9 1) المادة (9 (1) من نظام التحكيم ، محمد الهوشان ، "موقف القضاء التجاري الـسعودي

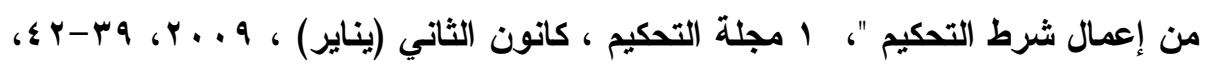
. $\{1-\varepsilon$.

• •

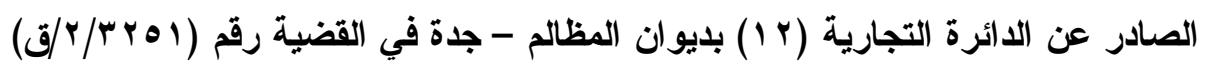

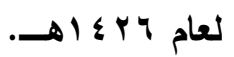

اYY) منصور بن حمد المالك، ندوة الإتحاد الدولي للمحامين عن التحكيم من منظور إسلامي

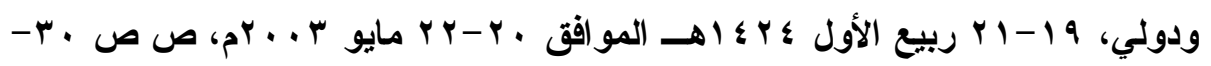
ـ 
د. ر نايف بن سلطان الشريف

فهو مرتبط بإطار زمني محدد وهو بذلك يتنافى مع فكرة التأبيد.(r) لذلك فإن إصدار هيئة التحكيم لحكمها مرتبط بالمدة المحددة في الوثيقة وإذا لم تتضمن الوثيقة مدة معينة فإن الحكم يجب أن يصدر خلال مدة معينة تبدأ

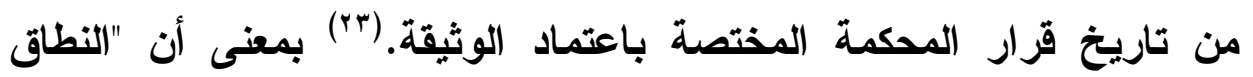
الزمني لخصومة التحكيم لاسيما المدة التي يجب إصدار حكم التحكيم التهائي قبل انقضائها يرتبط ارتباطاً لا يقبل الاتفصام بولاية هيئة التحكيم

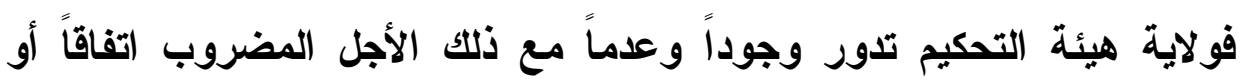
قاتوناً." (r)

القرع الثاني : الأثز القانوني لتجاوز حكم المحكمين للمدة التظامية من خلا استقراء وتحليل مختلف القوانين والقواعد فإن الأجل الأي يلزم إصدار حكم التحكيم النهائي خلاله يثير العديد من المشكلات والمسائل الاقيقة والتي تستوجب دراسة متعمقة تتناول تكييف التنظيم التشريعي للمدة بين الطابع الأمر والمكمل ، وسلطة القضاء إزاء طلب الإههاء ومسؤولية هيئة التحكيم و/ أو مؤسسات ومراكز التحكيم حيال إنهاء الإجراعات وكذلك أثز

r r r محمد صلاح الدين عبد الوهاب ، "إنهاء إجراءات التحكيم لتجاوز المدة بين ســلطان

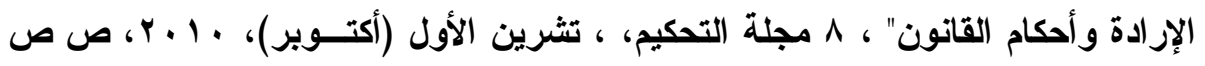
(1)

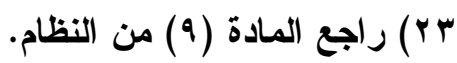

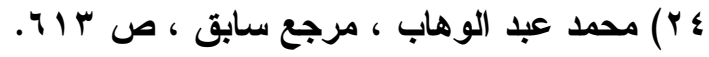


د. ر نايف بن سلطان الشريف

الإنهاء على أتفاق التحكيم. (ro)(استعرض نظام التحكيم "مدة حكم التحكيم" في مادتين هما؛ المادة التاسعة والمادة الخامسة عشرة وقد نصث الأولى على

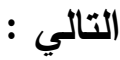

"يجب الحكم في النزاع في الميعاد المحدد في وثيقة التحكيم ما لم يتفق على تمديده وإذا لم يحدد الخصوم في وثيقة التحكيم أجلاً للحكم وجب على المحكمين أن يصدروا حكمه خلا تسعين يوماً من تاريخ صدور القرار باعتماد وثيقة التحكيم وإلا جاز لمن شاء من الخصوم رفع الأمر إلى الجهة المختصة أصلاً بنظر النزاع لتقرر أما النظر في الموضوع أو مد الميعاد لفترة

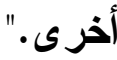

ولمعرفة الأثر القاتوني المترتب على الحكم الأي تجاوز الأجل وعما إذا كان ذلك الأجل يعتبر من النظام العام لا ، فإن الحاجة تظهر لاستعراض عدد من مواد النظام ولائحته التنفيذية. (1) تحديا ميعاد صدور الحكم في وثيقة التحكيم أوضحت المادة (9) أعلاه أنه إذا حدد الأطر اف أجلاً في وثيقة التحكيم واشترطوا صدور حكم هيئة التحكيم خلاله فإنه يتعين التزام الهيئة بهذا الأجل ما لم يتقق الأطر اف على تمديد الأجل بشكل مكتوب. وعند انتهاء الأجل تنتهي ولاية هيئة التحكيم المستمدة من إرادة الأطر اف ويكون الحكم بعد ذلك باطلاً

ه r) محمد صلاح الدين عبد الوهاب ، "إنهاء إجراءات التحكيم لتجاوز المدة بين ســلطان

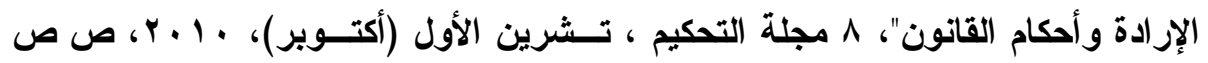
(2)

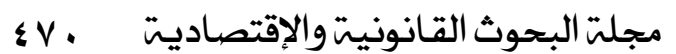


لصدوره ممن لا ولاية له. (ب) وإذا لم يحدد الأطراف أجل للحكم فإنه يجب على هيئة التحكيم أن تصدر قرارها خلال ( • (9) يوماً من تاريخ اعتماد وثيقة التحكيم. أن هذه المدة لا تعتبر من النظام العام إذ أن النظام يقضي بأن ينتهي

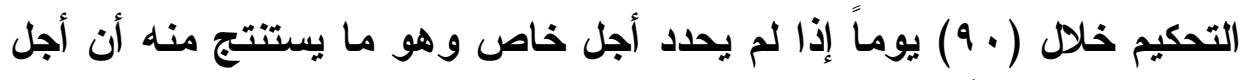

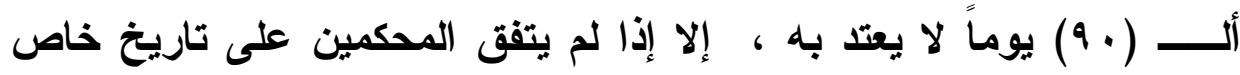

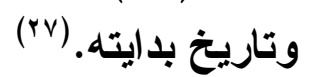

(r) ضو ابط تمديا ميعاد صدور الحكم

أن تمديد ميعاد صدور حكم التحكيم يخضع لضوابط محددة هي كالتالي :

$$
\text { (أ) وفاة أحد الخصوم }
$$

طبقاً للمادة (T) من النظام "لا ينقضي التحكيم بموت أحد الخصوم و إنما يمد الميعاد المحدد للحكم ثلاثين يوماً ما لم يقرر المحكمون تمديد المدة

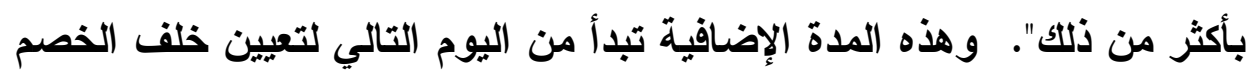
المتوفى سواء كان ذلك التعيين نتيجة أتفاق بين الورثئة أو عن طريق الجهة المختصة "وبعد أن يتم تعيين من يخلف الخصم المتوفى ، يستكمل الميعاد

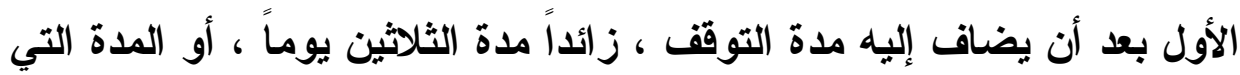

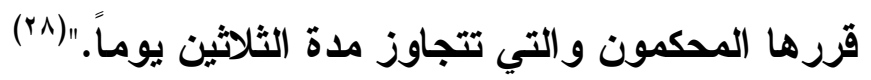

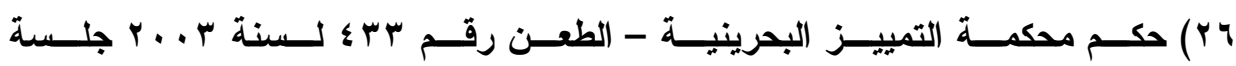

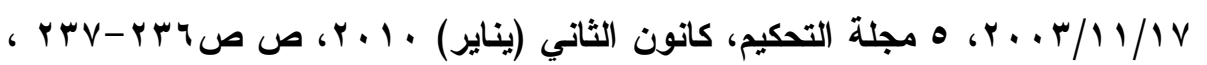

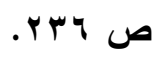

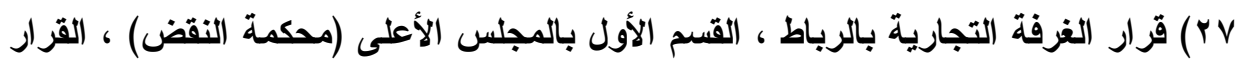

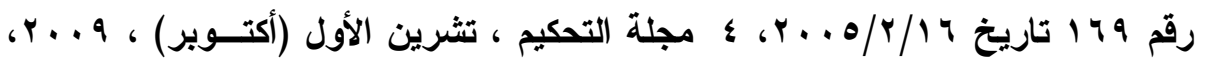
$.0 \leq \leqslant 60 \leqslant 0-0 \leqslant \mu$

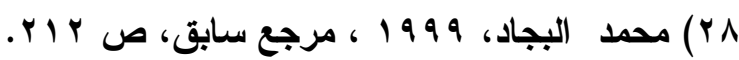
EVI مجلة البحوث القانونيت والإقتصاديت 
(ب) زوال صفة المحكم طبقاً للمادة (ع 1) من النظام "إذا عين محكم بدلاً عن المحكم المعزول أو

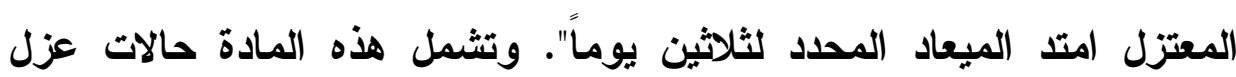
المحكم أو اعتزاله أو وفاته أو عجزة أو رده وتبدأ مدة التمديد من تاريخ تعبين المحكم الجديد مع وجوب إضافة مدة ميعاد المسافة إذا كان المحكم المعين لا يقيم في نفس المكان الأي ينظر فيه النزاع ومع ذلك فإن المادة ( ا () لا تشمل حالة غياب المحكم أو غيابه لأي أسباب أخرى لأن صفة المحكم لا تزول في مثل هذه الحالة. (9ولم يبين النظام الجهة المعنية بالنظر في طلب تعيين المحكم البديل في حالة زوال صفة المحكم ومع ذلك فإن تعيين المحمم البديل يجب أن يخضع لذات الإجراعات التي تتبع في اختيار سلفه بمعنى آخر أن الجهة المختصة بالفصل في النزاع يجب أن تعتمد قرار هيئة التحكيم بتعيين المحكم البديل وذلك انسجاما مع المادة (0) من النظام ويخضع قرار هذه الجهة للطعن طبقاً للمادة (1 I). ولحسن الحظ فقد تلافي مشروع النظام الجديد مثل هذه التعقيدات إذ حظر الطعن بأي طريق من طرق الطعن في قرار الجهة المختصة بتعيين المحكم.(·) (ج) التمديا بناءً على رغبة هيئة التحكيم طبقاً للمادة (0 10) من النظام "يجوز للمحكمين بالأغلبية التي يصدر بها الحكم وبقرار مسبب مد الميعاد المحدد لظروف تتعلق بموضوع النزاع". ولم يحدد النظام ماهية الظروف المتعلقة بموضوع النزاع وقد يكون المقصود بها حجم وتعقد القضية ومدة الخلاف بين الخصوم فكل هذه المسائل تلعب دور 
د. ر نايف بن سلطان الشريف

كبير - من وجهة نظر المحكمين - في مد ميعاد الحكم. ولكي يكون قرار هيئة التحكيم بامتداد أجل التحكيم صحيحاً فإن ثمة ضوابط يجب على ملئم الهيئة مر اعاتها وهي كالتالي :

• أن يكون الظرف الأي من أجله تم التمديد متعلقاً بموضوع النزاع ومرتبط به ارتباطاً مباشراً. • أن يصدر من الهيئة قرار يتضمن مد أجل التحكيم. • أن يتم توضيح الأسباب التي أدت إلى تمديد أجل التحكيم.

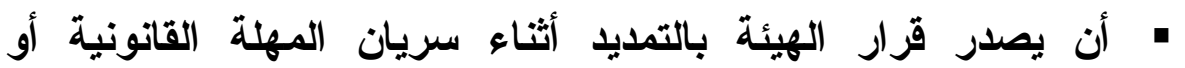
الاتفاقية.

(د) أتفاق الخصوم على التمديد إذا كان النظام قد خول الخصوم الحق في إنهاء أتفاق التحكيم في أي مرحلة من مراحل الاعوى فإن النظام خولهم كذلك الحق في تعديل شروط الاتفاق. ولألك منحت المادة التاسعة الخصوم إمكانية تمديد أجل التحكيم حيث نصت على أنه "يجب الحكم في النزاع في الميعاد المحدد في وثيقة التحكيم ما لم يتفق على تمديده". ويجوز تمديا مهلة التحكيم الاتفاقية أو القانونية أما وئ فئ باتفاق الخصوم وأما بقرار قضائي بناءً على طلب الخصوم أو الهيئة التحكيمية ويجب أن يقدم طلب تمديد مهلة التحكيم من القضاء أثناء سريان مهلة التحكيم القانونية أو الاتفاقية. (آ") ولتفادي لجوء أحد الخصوم إلى المحكمة المختصة بغرض النظر في موضوع النزاع بسبب تجاوز المحكمين للمدة النظامية فإنه

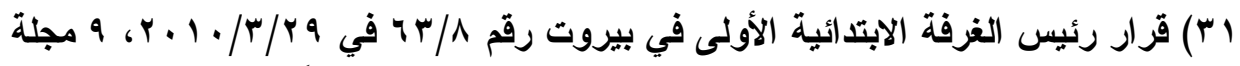

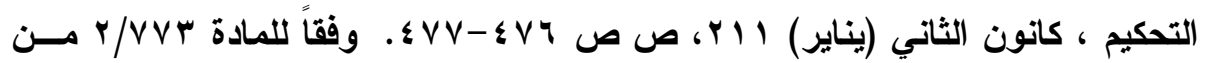

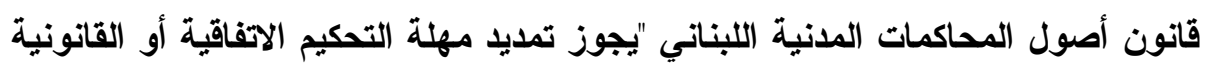

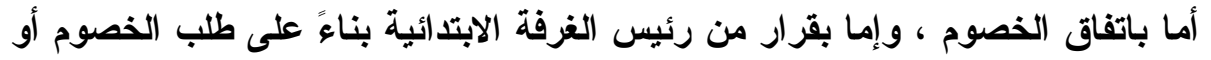
الهيئة التحكيمية." مجلتة البحوث القانونيت والإقتصاديت 
يمكن لهيئة التحكيم أخذ موافقة الخصوم على تمديد آجل نظر النزاع وربط مد

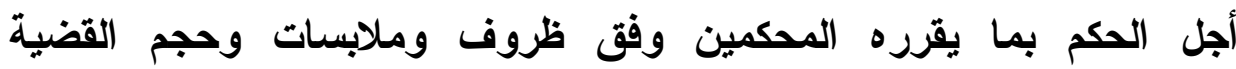

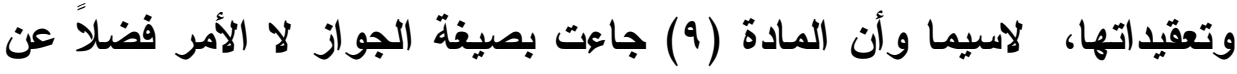

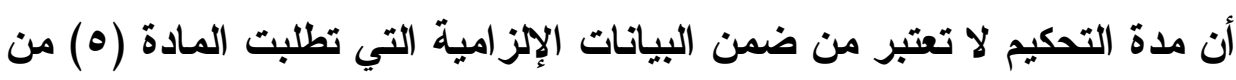

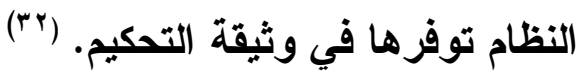
ورغم ذلك فإن أتفاق الخصوم على التمديد يأخذ عدة صور فقا يكون

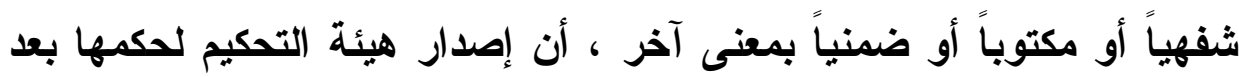

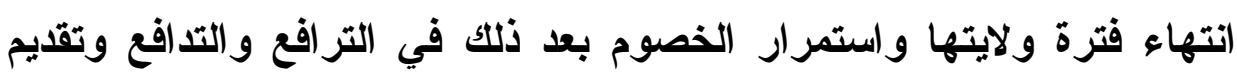

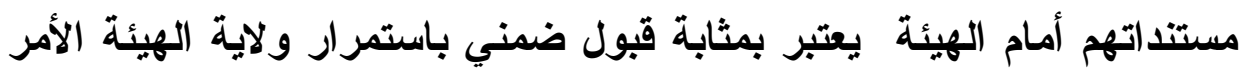

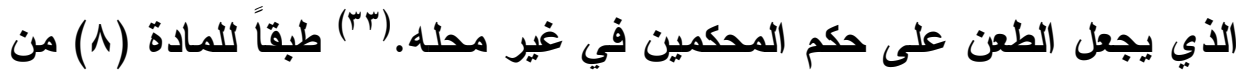

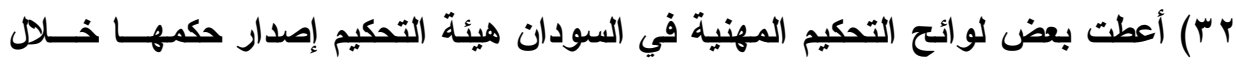

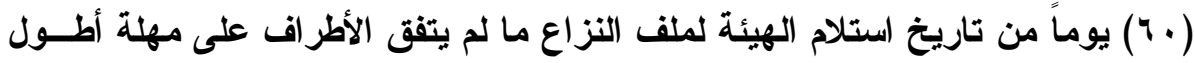

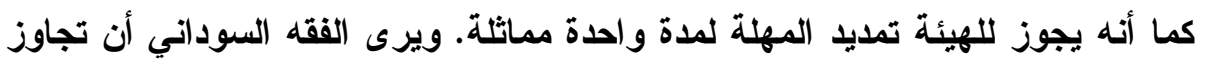

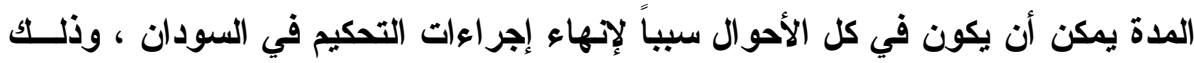

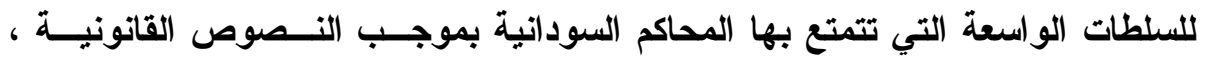

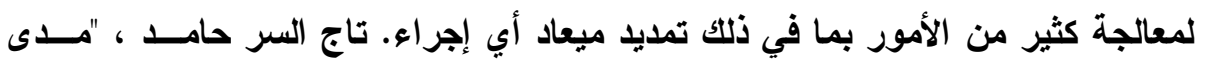

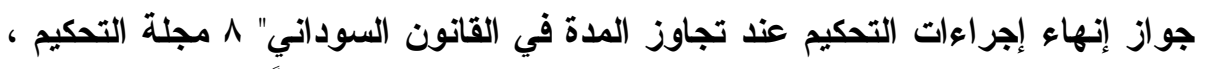

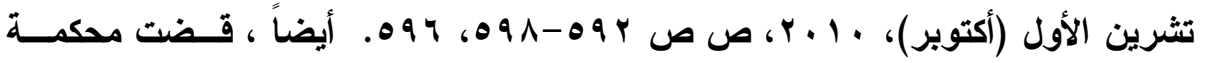

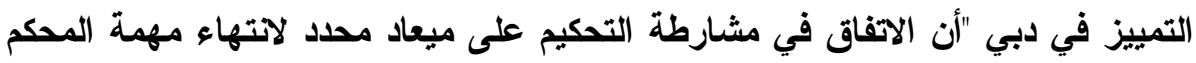

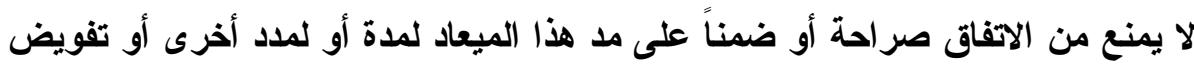

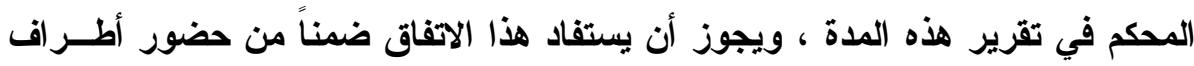

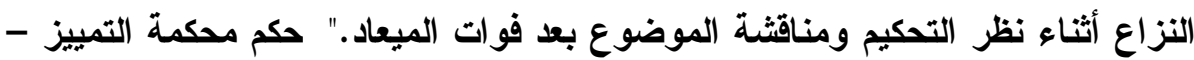

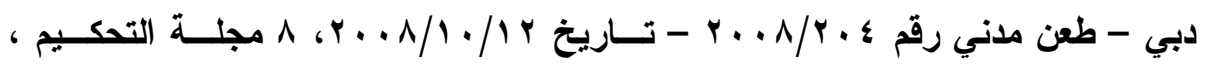

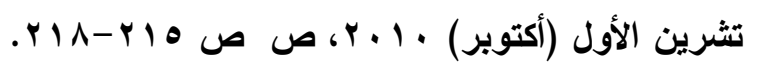

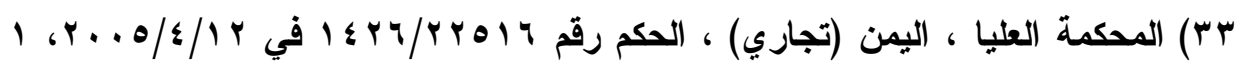

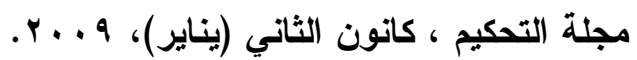


قانون التحكيم المصري "... إذا استمر أحد طرفي النزاع في إجراعات التحكيم مع علمه بوقوع المخالفة لشرط اتفاق التحكيم أو لحكم من أحكام هذا القانون مما يجوز الاتفاق على مخالقته ، ولم يقدم اعتر اضاً على هذه المخالفة في الميعاد المتفق عليه أو في وقت معقول ، عند عدم الاتفاق ، اعتبر ذلك نزولاً منه عن حقه في الاعتر اض." (ء) وق قضت محكمة استئناف القاهرة على أن عدم الاعتر اض من قبل صاحب المصلحة دلالة على الرضا وهو يزيل المخالفة التي شابت الإجراء ويصححها ولا يجوز له أن يعود أمام محكمة البطلان ويثير ما سبق أن نزل عن حق الاعتراض عليه أمام هيئة التحكيم تأسيساً على قاعدة "الساقط لا يعود".(r)" ومؤدى ذللك أنه لا يجوز للخصوم تقديم دفوع جديدة أمام محكمة النقض تقوم على واقع لم يثبت إثارته أمام محكمة الموضوع - هيئة التحكيم - فمسألة مجاوزة الوكيل حدود وكالته من مسائل الواقع التي تستقل محكمة الموضوع بتقديره. (־") أن دفع أحد الخصوم باتتهاء ولاية هيئة التحكيم في مثل هذه الحالة يتناقض مع الآية الكريمة (فمن نكث

؛ ب) في ذات المعنى قضت المادة (V) من قانون التحكيم الأردني.

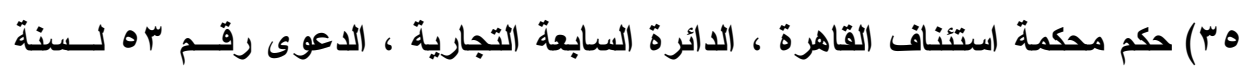

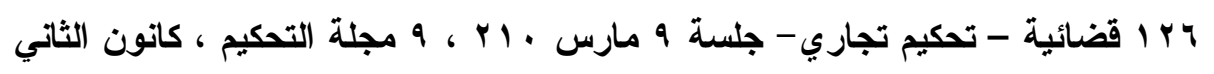

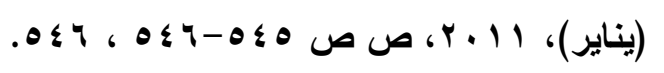

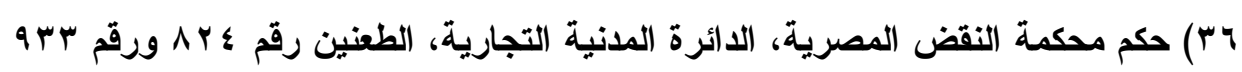

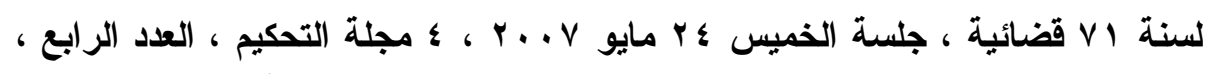

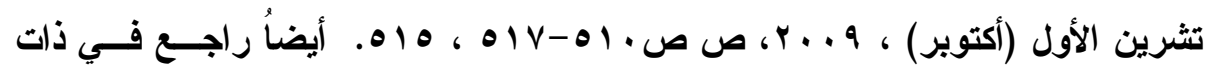

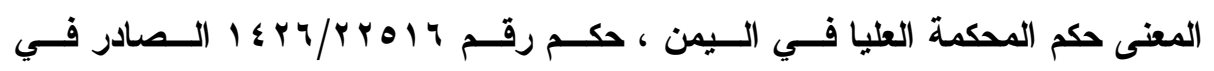

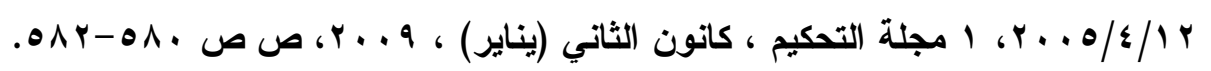

SVD مجلت البحوث القانونيت والإقتصاديت 
فإنما ينكث على نفسه)(rv) والقاعدة الفقهية "من سعى في نقض ما تم من جهته فسعيه مردود عليه". "وقد قرر العلماء أن دلاكة الحال كالصريح من الأقوال وهي معتبرة شرعاً ، نص على ذلك شيخ الإسلام ابن تيميه والعز بن عبد السلام والإمام أبن رجب والإمام أبن القيم وهو المذهب المشهور عن الإمام مالكك والإمام أحمد رحمهم الله ، قال الإمام الكرخي في قواعد (الأصل أن

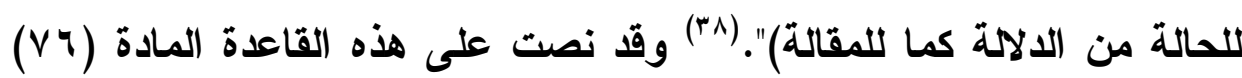
من مشروع قانون المعاملات المالية العربية الموحد وهي قاعدة واجبة التطبيق في المنازعات التجارية التي ينص الاتفاق التحكيمي فيها على الفصل في الخصومة بمقتضى أحكام الشريعة الإسلامية ، أو بما لا يتناقض وأحكام الشريعة الإسلامية ، أو الاتفاق التحكيمي الذي ينص على أن القانون الواجب التطبيق على موضوع أو إجراعات النزاع هو قانون يعتمد على هذه القاعدة

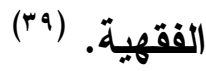

(هـ) الفصل في مسألة أولية عارضة تخرج عن اختصاص هيئة التحكيم عندما يظهر لهيئة التحكيم مسألة مرتبطة بموضوع النزاع وهذه المسالة تخرج عن اختصاص الهيئة كثبوت واقعة تزوير في محرر رسمي فإن مرن

$$
\text { (rV }
$$

^r منصور بن حمد المالك، ندوة الإتحاد الدولي للمحامين عن التحكيم من منظور إسلامي

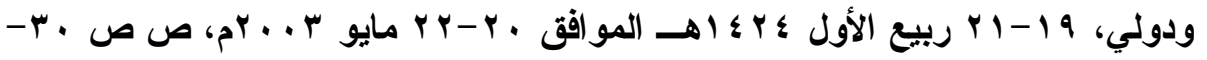

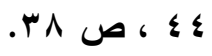

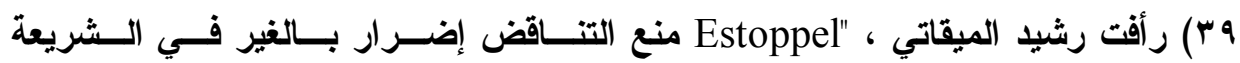

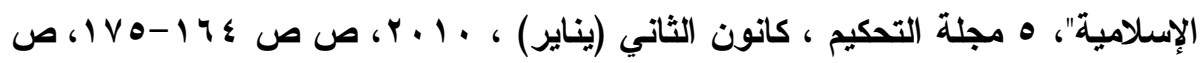


د. ر ايف بن سلطان الشريف

إجراءات التحكيم تثوقف إلى حين صدور قرار من المحكمة أو الجهة المختصة بثبوت أو نفي الواقعة. وقد قضت المادة (rv) من اللائحة التنفيذية للنظام بأنه "إذا عرضت خلا التحكيم مسألة أولية تخرج عن ولاية هيئة التحكيم أو طعن بتزوير في ورقة أو اتخذت إجراعات جنائية عن تزويرها أو عن حادث جنائي آخر أوققت الهيئة عملها ، ووقف الميعاد المحدد للقرار إلى أن يصدر حكم نهائي من الجهة المختصة بالفصل في تلك المسألة

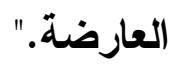


المبحث الثاني : المحكمة المختصة بنظر دعوى بطلان أحكام التحكيم تمهيد

إذا اثتتمل حكم التحكيم على ما يخالف النظام العام والآداب في المملكة فإن الجهة المختصة بتفيذ حكم التحكيم تقضي بالبطلان من تلقاء نفسها. كما

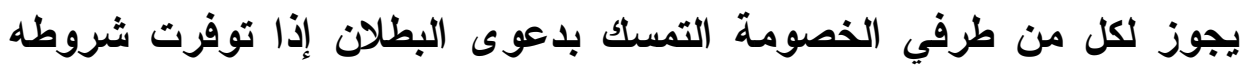

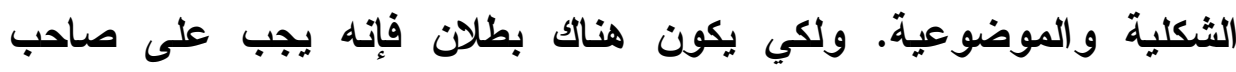
المصلحة مر اعاة إجراعات رفع دعوى بطلان حكم التحكيم والمحكمة المختصة ولئه بنظر دعوى البطلان.

ينقسم هذا المبحث إلى فرعين هما : إجراءات رفع دعوى البطلان و المحكمة المختصة بنظر دعوى البطلان. الفرع الأول : إجراءات رفع دعوى البطلان جميع الأحكام الصادرة من المحكمين يجب إيداعها خلا خمسة أيام لاى

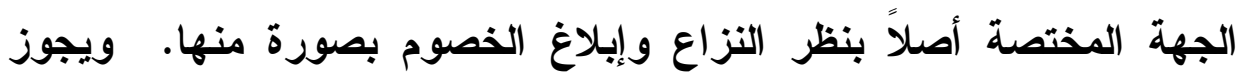

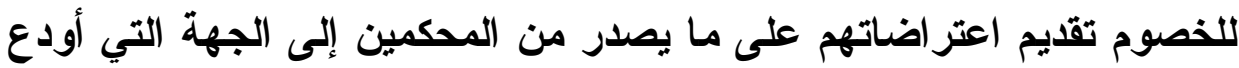

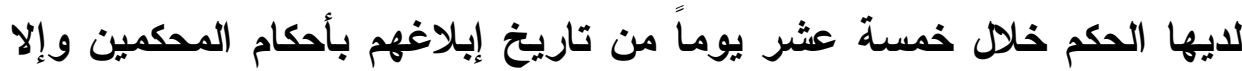

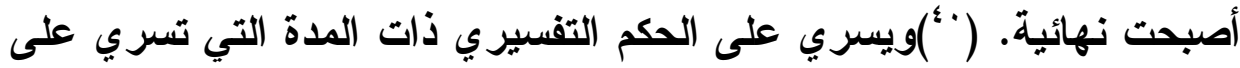

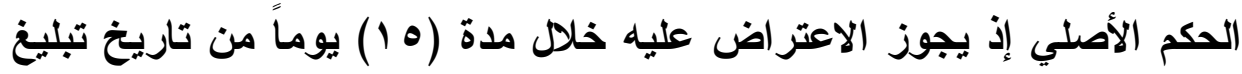

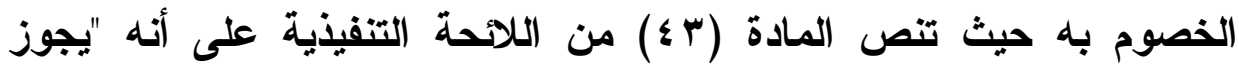

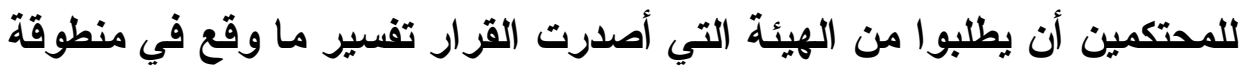

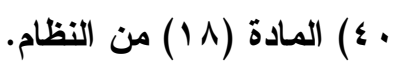


من غموض أو إبهام ويعتبر القرار الصادر بتفسير متمماً من كل الوجوه للقزار الأصلي ويسري عليه ما يسري على هذا القرار من القواعد الخاصة بطرق الطعن." ويعد إعادة ملف القضية إلى هيئة التحكيم بغرض تفسير الحكم أو استدر الك بعض طلبات الخصوم من الحالات الاستثنائية على قاعدة استنفاذ

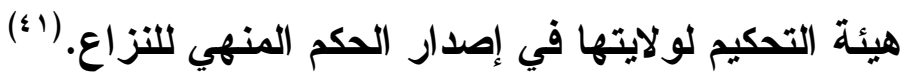

يقصد بتفسير الحكم توضيح ما يعتريه من غموض وإظهار حقيقة المبهم فيه بهرف تحديد مضمون الحكم عن طريق العناصر المكونة له."(rء) ويقتصر دور هيئة التحكيم على تحديذ مضمون الحكم الغامض وتوضيح حقيقة المقصود منه ولا يجوز لها أن تتخذ من التفسير وسيلة لإعادة النظر في الاعوى الأي صدر فيها الحكم بإلغاء الحكم أو تعديله وإلا كان حكمها قابلاً للطعن فيه تأسيساً على أن الهيئة قد تجاوزت نطاق مهمة التفسير ويعد الحكم التفسيري مكملاً للحكم - محل التفسير - وتسري عليه أحكامهه. (باء) وحق هيئة التحكيم في تصحيح الأخطاء المادية يعتبر من الحقوق البديهية الأي تجيزه

(؛) يعقوب يوسف صرخوه، "ثروط صحة التحكيم في التشريع الكويتي مقارنة بمــا ورد

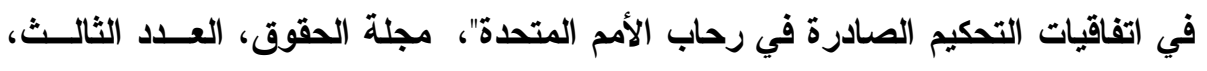
سبتمبر، و 199 r ؟ ) نجيب أحمد عبد الله ثابت الجبلي ، التحكيم في القوانين العربية : دراسة مقارنة فـي

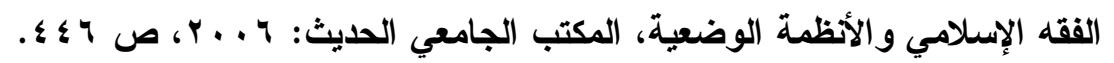

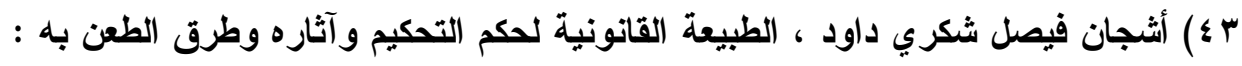

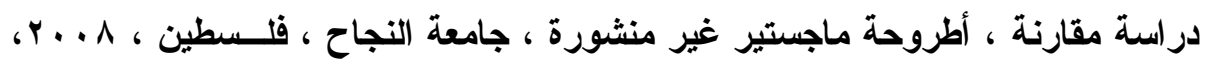
ص 79. 


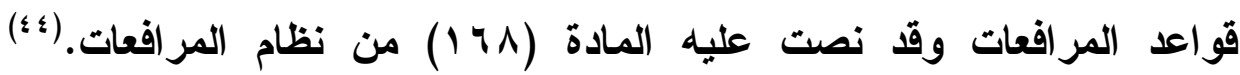
وتسري ذات المدة - 10 يوم من تاريخ تبليغ الخصوم به - على حالة صدور

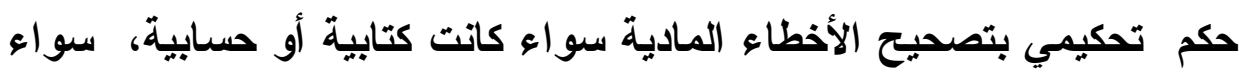
أصدرته هيئة التحكيم من تلقاء نفسها أو بناءً على طلب أحد الخصوم كما يجوز التمسك ببطلان الحكم بدعوى مستقلة عند تجاوز هيئة التحكيم صلاحيتها في التصحيح. (0؛) ولا يجوز الطعن في القزار الصادر برفض التصحيح بطلب مستقل عن طلب الطعن في الحكم الأصلي الأي ورد فيه الخطأ المادي تأسيساً على أن الإجازة في مثل هذه الحالة قد تؤدي إلى تأخير الفصل في النزاع إذا تقدم الخصوم بطلبات تصحيح غير جدية.("؛) ويشترط لقبول طلب تصحيح الأخطاء المادية أن يكون للخطأ المادي أساس في محضر الجلسة أو في مستندات الدعوى يال على الواقع الصحيح فيه بحيث يظهر الخطأ عند مقارنته بالثابت في المستندات. (؟v) ولا يشترط في طلب تصحيح الحكم تقديمه من قبل أحد الخصوم إذ يجوز للهيئة أيضاً استناداً إلى سلطتها التقديرية تصحيح

؛ ؛) وفقا لهذه المادة " تتولى المحكمة بقرار تصدره بناءً على طلب أحد الخصوم أو مسن تلقاء نفسها تصحيح ما قد يقع في صك الحكم من أخطاء مادية بحتة كتابية أو حسابية ، ويجري هذا التصحيح على نسخة الحكم الأصلية ويوقعه القاضي أو قضاة المحكمة التي أصدرته بعد تدوين القرار في ضبط القضية."

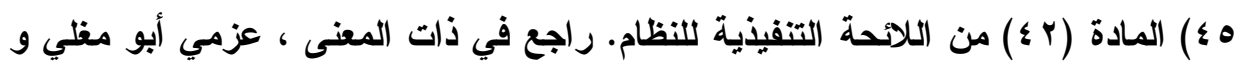

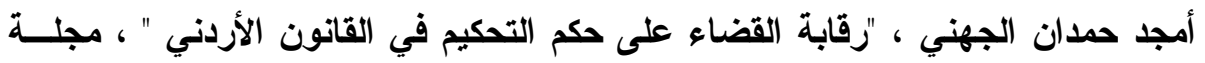

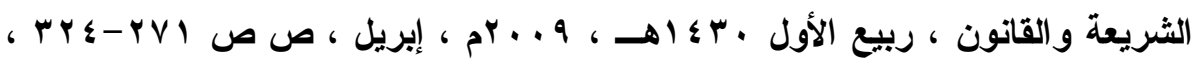
. YAV

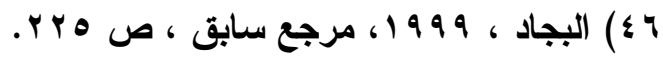

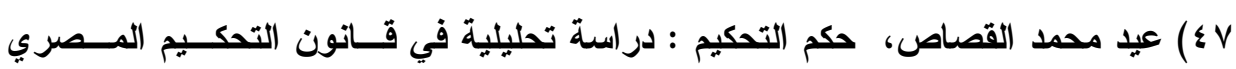

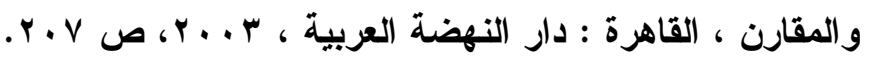


الأخطاء الواردة في حكمها وهذا خلاف حالة غموض الحكم إذ أنه يشترط في

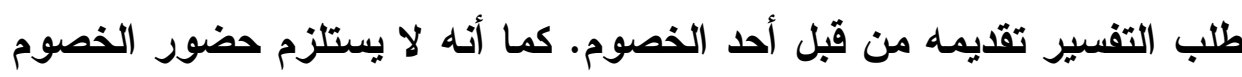

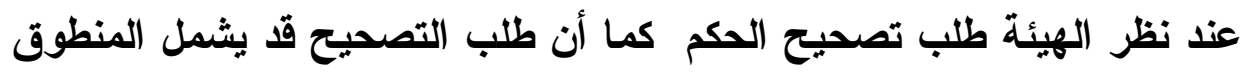

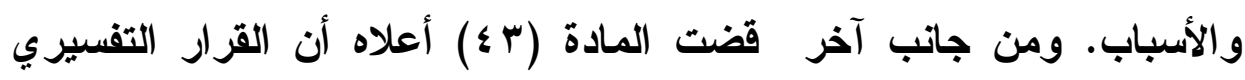

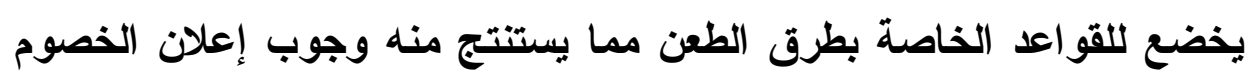
بجلة التفسير وطرح الخصوم دفوعهم بثأن التفسير على الهيئة وكنلك الحق في الاعتراض على الحكم التفسيري خلا مدة (10) يوم من فئل

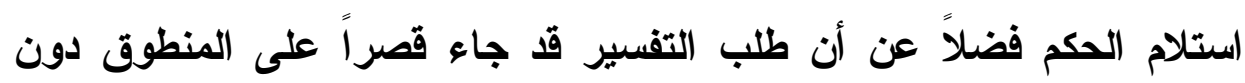
الأسباب.

أثبت الواقع العملي أن طلبات تفسير أحكام التحكيم قـ تستغرق وقت

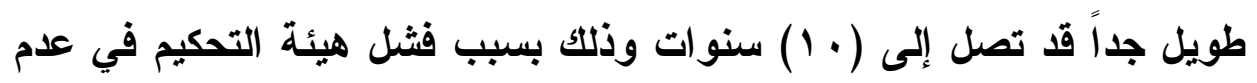

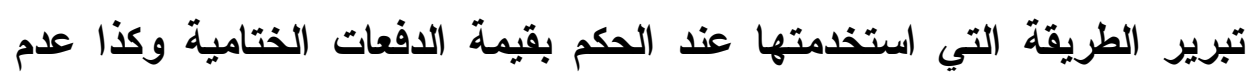

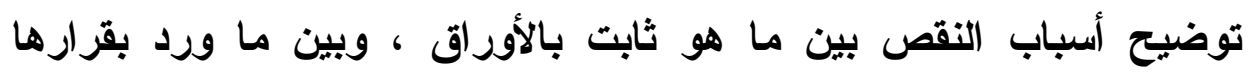

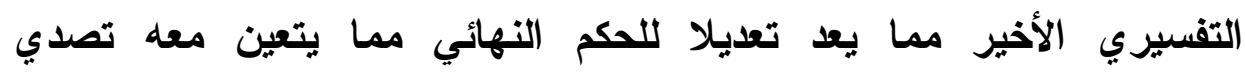
الدائرة التجارية المختصة للاعوى بسبب تعذر الفصل فيها من قبل هيئة

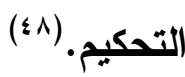

يعاب على اللاحة التنفيذية عدم تحديدها لمهلة زمنية يتم خلالها إصدار

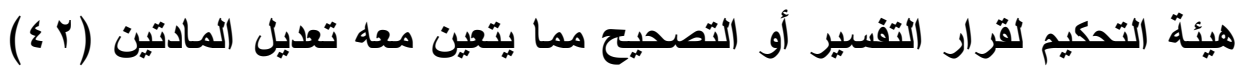

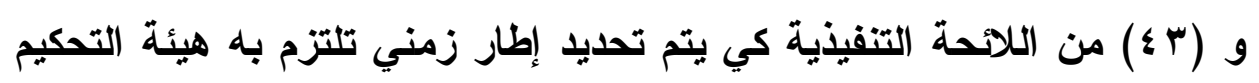

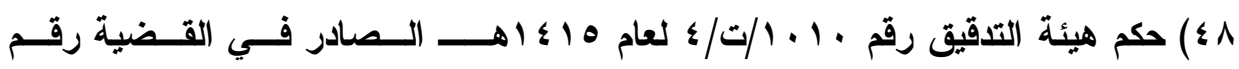

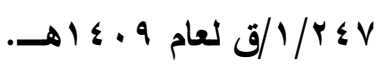

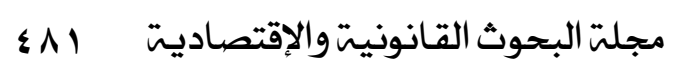


عند نظر طلبات التفسير أو التصحيح.(9) ورغم ذلك فقد تدارك مشروع النظام الجديد هذا القصور وحدد المدة التي يجب أن يصدر خلالها القزار التفسيري أو التصحيحي بمدة ( • ب) يوماً تبدأ من تاريخ تقديم طلب التفسير

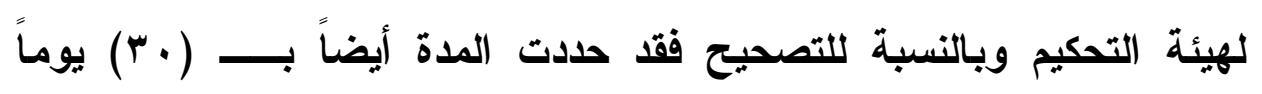
التالية لتاريخ صدور الحكم ، أو إيداع طلب التصحيح بحسب الأحوال. وفي الحالتين أجاز مشروع التظام لهيئة التحكيم مد ميعاد نظر طلب التفسير أو تصحيح ما يقع في حكمها من أخطاء مادية بثلاثين يوماً حسبما تقتضيه الضرورة. (ن)

من جاتب آخر فإن النظام ولاتحته التنفيذية لم ينظما مسألة التحكيم الإضافي أو المدة التي يجب خلاهها التقدم بالتظلم على حكم التحكيم عند إغفال

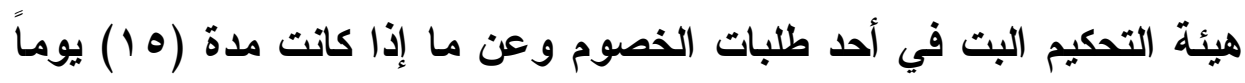
أعلاه تسري على هذه الحالة أم لا ؟

في ظل هذا الفراغ التنظيمي فإنه - ومن الناحية النظرية على الأقل و قياساً على السماح لهيئة التحكيم بتفسير وتصحيح الأخطاء الواردة في الحكم فإنه يجوز لها إصدار حكم إضافي فيما أغفلته من طلبات - سواء كاتت طلبات كلية أو جزئية - لأن الأصل "أن يكون الحكم المنهي للنزاع شاملاً

9 §) نصت المادة (0 §/ب) من قانون التحكيم الأردني على أن "يصدر التفسير كتابة خــلال

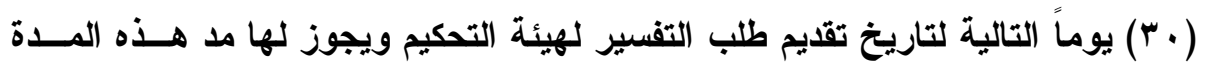

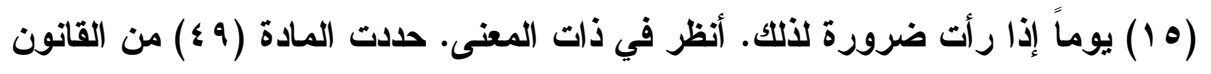
المصري مد المدة المتعلقة بتفسير الحكم بثلاثين يوماً.

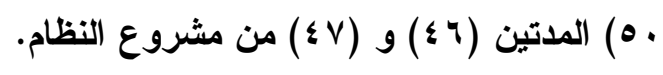


لجميع طلبات أطراف النزاع".(10) ورغم ذلك فقد تضمن مشروع النظام الجديا في مادته (^ \& ) على أنه "يجوز لكل من طرفي التحكيم ولو بعد انتهاء ميعاد التحكيم مطالبة هيئة التحكيم خلال ( • ب) يوماً التالية لتشلم حكم التحكيم إصدار حكم تحكيم إضافي في طلبات قدم خلال الإجراعات وأغفلها حكم التحكيم ، ويجب إبلاغ الطرف الآخر على عنوانه الموضت في حكم التحكيم بهذا الطلب قبل تقديمه لهيئة التحكيم وتصدر هيئة التحكيم حكمها خلال ( • ج) يوماً من تاريخ تقديم الطلب ويجوز لها مد هذا الميعاد ثلاثين يوماً أخرى إذا رأت ضرورة لذلك."

الفرع الثاني : المحكمة المختصة بلعوى البطلان

عند اعتراض أحد الخصوم على حكم التحكيم أمام الدائرة التجارية المحكمة المختصة بالفصل في النزاع - فإنها أي الائرة تنظر في موضوع النزاع ويتخذ قر ارها صورتين : بهن

(1) رفض الاعتر اض على حكم التحكيم والأمر بتنفيذه.

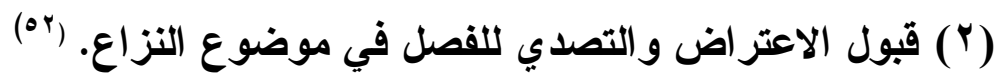

نتيجة لألك فإنه عندما يتم الاعتراض على حكم التحكيم خلال المهلة النظامية - (0 1 ) يوماً التالية لإبلاغ الخصوم به - فإن الجهة المختصة أصلاً بالفصل في النزاع تنظر في الاعتراض وإذا قررت رفض الاعتر اض فإنها تأمر

10) أثجان داود ، مرجع سابق، ص VN. عالج كلاً من القــانون المــري و القــانون

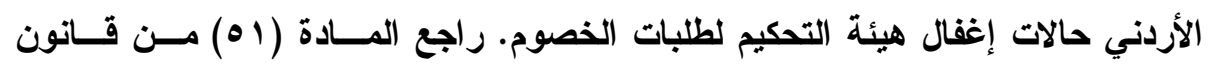

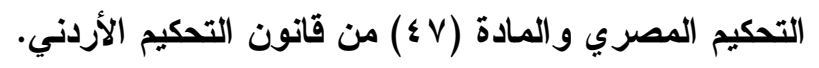

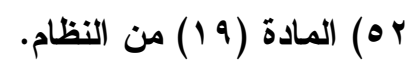


د. ر نايف بن سلطان الشريف

بتنفيذ الحكم التحكيمي ويعتبر قرارها نهائياً لا يجوز الطعن عليه أمام هيئة التدقيق. وغني عن القول أن حكم التحكيم يكون نهائياً أيضاً إذا لم يتم الاعتراض عليه من قبل الخصوم خلا المدة أعلاه. أما إذا تم قبول الاعتراض من قبل الجهة المختصة أصلاً بالفصل في النزاع فإن هذه الجهة تتصدى للفصل في الاعتر اض ويكون قرارها قابل للاعتراض عليه أمام هيئة التدقيق (محكمة الاستئناف). (r) وهذا الوضع يتماشى مع التوجه الأي سلكته بعض

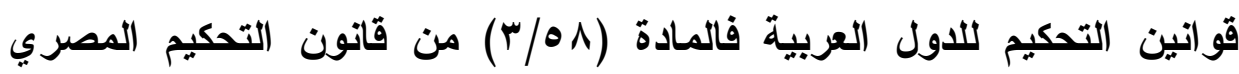
تقضي بعدم جواز التظلم من الأمر الصادر بالتنفيذ ، أما الأمر الصادر برفض التفيذ فيجوز التظلم منه إلى المحكمة المختصة أصلاً بنظر النزاع خلا ( • ب) يوماً من تاريخ صدوره.(๕) كما قضت المادة (1 ه) من قانون التحكيم الأردني "إذا قضت المحكمة المختصة بتأييا حكم التحكيم وجب عليها أن تأمر بتنفيذه ويكون قرارها في ذلك قطعياً. وإذا قضت ببطلانه فيكون قرارها قابلاً للتمييز خلال ( • ب) يوماً من اليوم التالي للتبليغ ويترتب على القرار القاضي ببطلان حكم التحكيم سقوط أتفاق التحكيم."

ورغم ذلك فِإن الاجتهاد القضائي في المملكة قد خالف ما قضى بـه النظام. ففي الحكم رقم (V/ت/T لعام 9 إـ اهـ) الصادر في تنفيذ حكم التحكيم

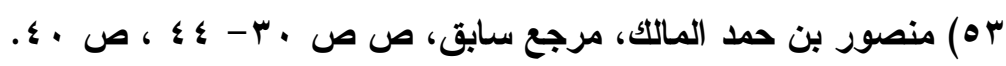

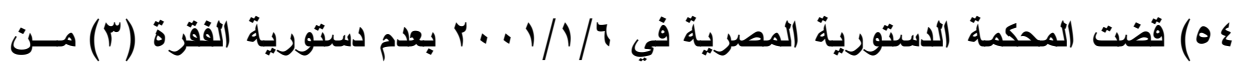

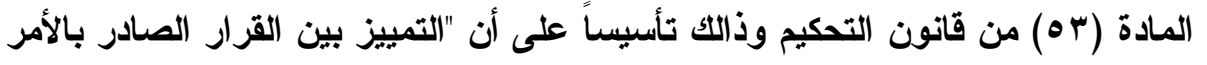
بالتتفيذ ، وبين القرار الصادر برفضه من حيث إمكانية الطعن عليه يشكل إخلالاً بمبــــأ

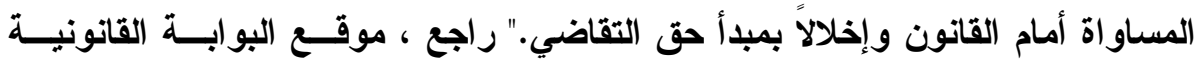

الاككتروني، التطبيقات العملية لقضاء المحكمة الاستورية العليا : http://www.tashreaat.com/view_studies2.asp?id=90\&std id=37

مجلتّ البحوث القانونيت والإقتصاديت ع ؛ 
الوطني رقم \& 1 العام 1 أ أهـ ، أستلم طرفا النزاع صورة من إعلان الحكم واعترض عليه أحد الخصوم خلا المهلة النظامية المحدة في المادة (1^) من النظام. وعليه نظرت الجهة المختصة أصلاً بنظر النزاع في اعتراض المحكوم ضدها وقد قضت بالتالي: أولاً : قبول اعتر اض المدعى علها شكلاً ورفضه موضوعاً. ثانياً : تأييد حكم المحكم المنفرد فيما قضى به. وقد وضحت الدائرة في أسباب حكمها "أنه بالإطلاع على أوراق القضية والحكم الصادر فيها من المحكم والاعتراض المقدم عليه من وكيل المدعى عليه ومناقشتها له وما ظهر لها (أي الأئرة) من قيام حكم المحكم على أسباب تبرره ومستخلصه استخلاصاً سائغاً من وقائع صحيحة وثابتة في أوراق القضية مما يتعين معه رفض الاعتر اض موضوعأ وتأييا حكم التحكيم." وقد استأنف المدعى عليه حكم الائرة أمام هيئة التاقيق - محكمة الاستئناف- وذلك بتقديم لاتحة الاعتراض خلا الأجل المحد نظاماً للاعتراض. وبنظر الهيئة للاستئناف أوضحت أنه "بالإطلاع على مستتدات القضبة بما فيها حكم التحكيم وحكم الائرة محل التدقيق والاعتر اض المقدم عليه. وحيث ظهر للهيئة أن حكم التحكيم قد استوفى مناقشة ما أثاره المعترض مفصلاً وخلص من ذلك إلى نتيجة سائغة صحيحة فإنها تتفق مع الائرة فيما خلصت إليه من عدم وجود ما يدعو إلى نقض حكم التحكيم أو تعديله مما

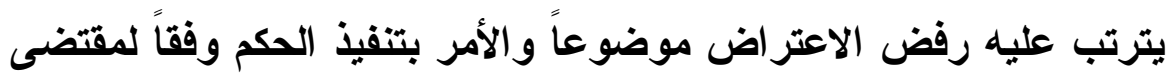
المادة (9 1 ) من نظام التحكيم.

وبهذا يتضح جسامة الخطأ الأي أرتكبه قضاة ديوان المظالم إذ أنهم أنشئوا بفهمهم الخاطئ للنظام درجة من درجات التقاضي لأحكام التحكيم مما 
يخالف التطبيق الصحيح للمادتين (1) 1) و (9 19) من النظام. أن مفهوم الجهة

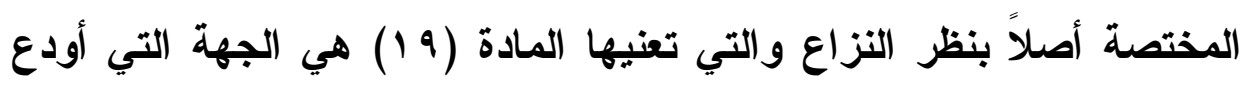

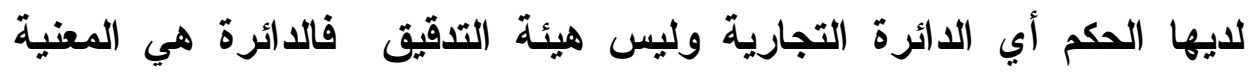

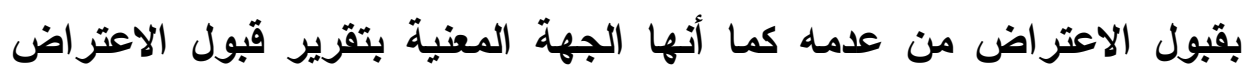

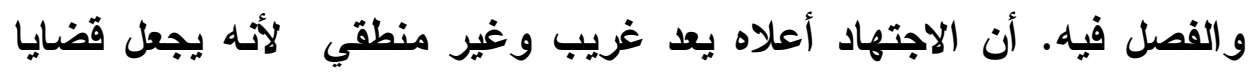

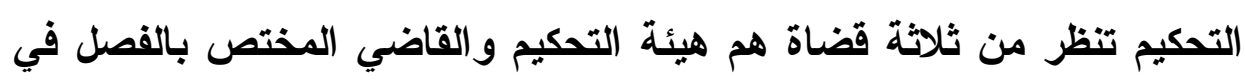

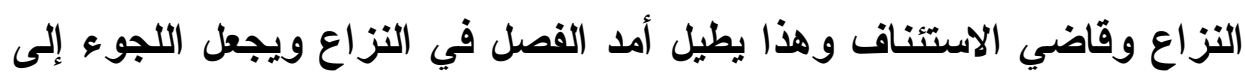
القضاء أكثر منطقية وواقعية من اللجوء إلى التحكيم الذي يصبح في هذه لأه

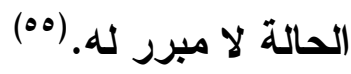

تضمنت المادة (9) من مشروع نظام التحكيم الجديد نصاً واضحا إذ أنها عقدت الاختصاص بنظر مسائل التحكيم لدرجة التقاضي الثانية للجهة القضائية

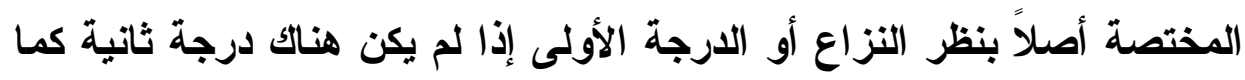

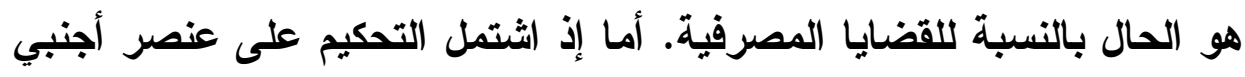

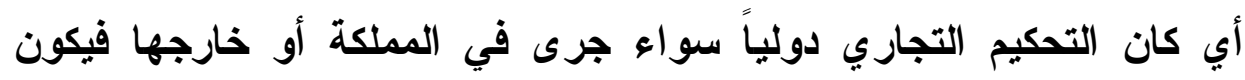

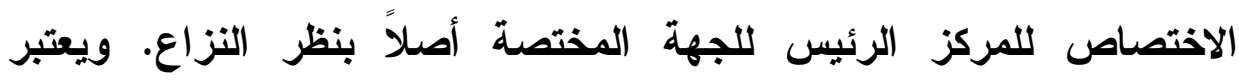

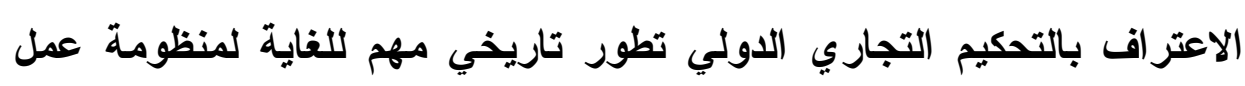

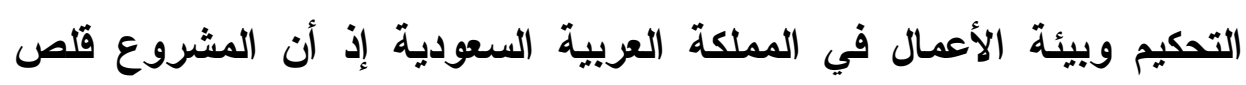
المسافة وضيق الهوة وقضى على أزمة الثقة التي كانت موجودة بين الثركات

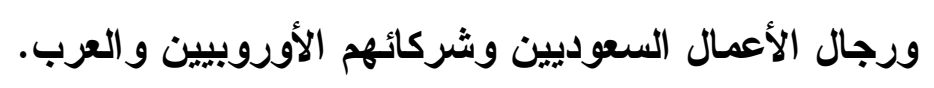

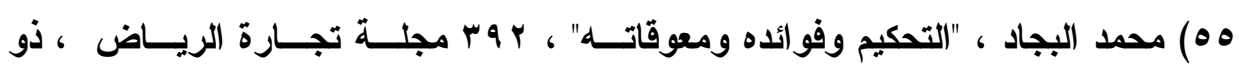

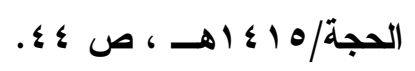


إضافة إلى ذلك فإنه وعلى خلاف الوضع الموجود في قوانين التحكيم في الدول العربية ،(4) لم ينظم نظام التحكيم ولاتحته التنفيذية دعوى بطلنا حكم التحكيم. وباستقراء نصوص النظام ولائحته يمكن إجمال دعوى بطلان حكم التحكيم في عدد من الحالات من أهمها :

ا ـ بطلان اتفاق التحكيم أو انتهاء مدة ولاية هيئة التحكيم. (ov)

r. فقدان أو نقص أهلية أحد طرفي اتفاق التحكيم. (^ه) r. مخالفة هيئة التحكيم لإجراعات الاعوى التحكيمية ومن أهمها الإخلال بحقوق الافاع ومبدأ المواجهة بين المحتكمين. (aه) ع. مخالفة حكم التحكيم لنظام التحكيم أو لاتحته التنفيذية. (·)

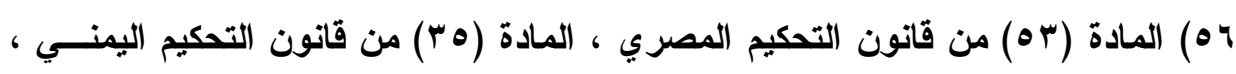

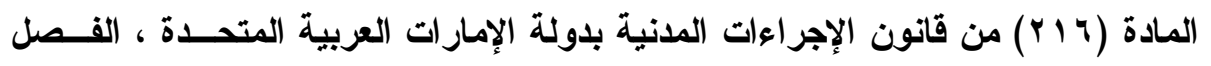

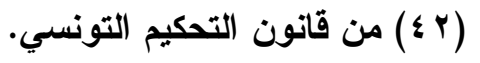

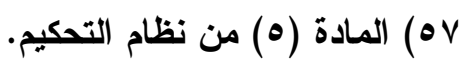

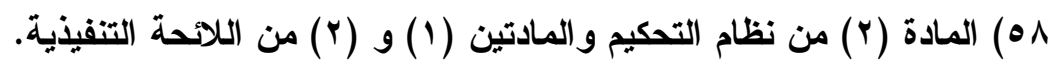

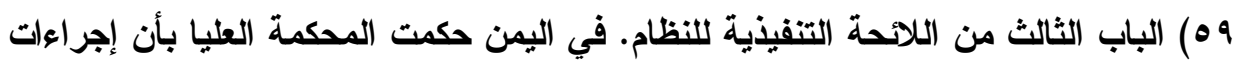

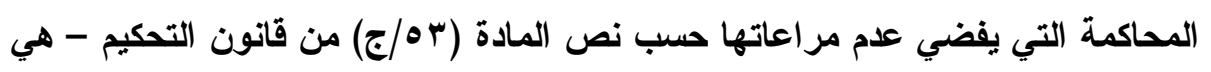

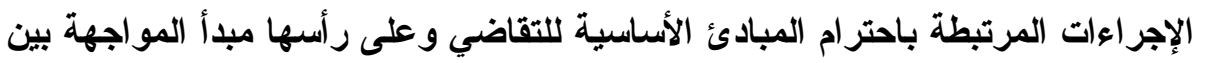

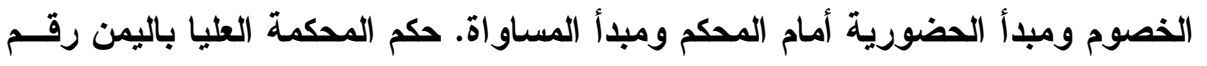

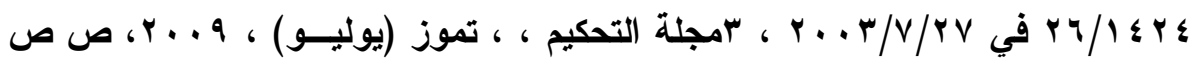

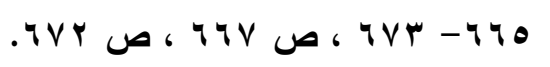

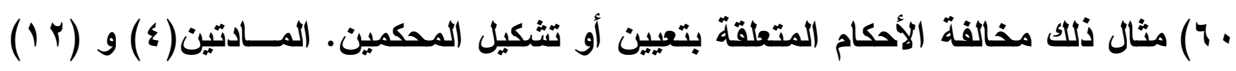

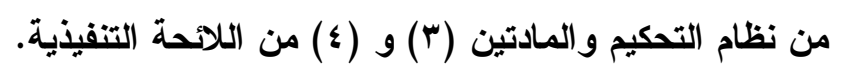


ه. عدم قابلية النزاع للتحكيم أو تضمن الحكم ما يخالف النظام العام في

(י) (لمملكة.

أن الملاحظ على النظام ولاتحته التنفيذية توسعهما في قبول دعوى بطلان حكم التحكيم ونستدل على ذلك بالآتي : أولاً : المادة (9 1 ) من نظام التحكيم

أن المادة (9 1 ) من نظام التحكيم خولت الخصوم حق الاعتراض على إم حكم المحكمين خلال (10) يوماً من تاريخ تبليغهم بالحكم. وهذا النص لم لم يفرق بين الطعون الشكلية والطعون الموضوعية لذا فإن نظر موضوع الاعوى من قبل القضاء في هذه الحالة يفرغ نظام التحكيم من غايته الأساسية ويجرده من مميزاته كوسيلة فردية لحل النزاعات التجارية وقد أثبت الواقع من من العملي أن النص يقضي بأن الطعن - الاعتر اض - يأخذ صفة طلب استئناف وتتظر الاعوى من قبل الدائرة التجارية باعتبارها جهة الاختصاص الأصلية وما يزيد هذا الأمر تعقيداً أن قرارها لا يعتبر نهائياً إذ أن لصاحب المصلحة حق الاعتر اض أمسام هيئة التدقيق وبهذا يكون التحكيم قد أضاف أعباء جديدة تمثلت بإيجاده درجة جديدة من درجات التقاضي. (זrأن أهم ما يميز التحكيم نهائية أحكامه وقد حرصت معظم قواتين التحكيم على تحقيق هذه النهائية إذ استبعدت إمكانية الطعن في أحكام التحكيم بالاستئناف وقصرت طرق الطعن في

آ) المادتين (r) و (r) من نظام التحكيم والمادة ( (1) من اللائحة التنفيذية.

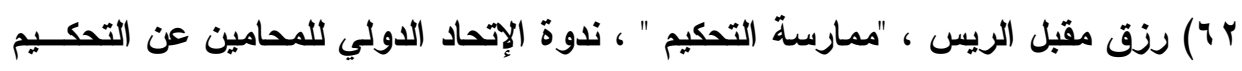

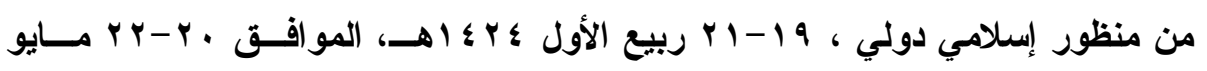

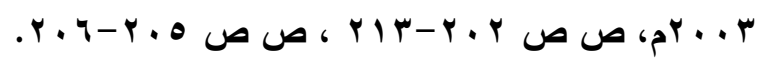

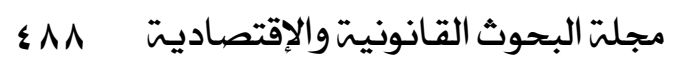


حكم التحكيم على وسيلة وحيدة هي دعوى بطلان حكم التحكيم ، وذلك استتاداً إلى أسباب شكلية محدودة واردة على سبيل الحصر تدور حول سلامة العملية التحكيمية من حيث الثكل والإجراعات بلاءاً من اتفاق التحكيم والأهلية اللازمة لإبر امه مروراً بنزاهة إجراعات التحكيم وعدالتها وضرورة احترام حقوق مقال الافاع ومبدأ سلطان الإرادة وكذلك صحة تشكيل هيئة التحكيم والتقيد بحدود ونطاق مهمة المحكمين وصحة حكم التحكيم وعدم مخالقته لاعتبار ات النظام العام.("آ) ولألك فإنه ينبغي على المشرع السعودي تعديل المادة (9 (1) من النظام بحيث يتم تضييق نطاق دعوى بطلان حكم التحكيم مما يؤدي إلى تقليل الوقت اللازم للوصول إلى نهائية أحكام التحكيم مما يجعل العملية التحكيمية أكثر فعالية. وقد تبنت قوانين التحكيم العربية مواقف حاسمة تجاه قصر بطلان

ب T) محمد عبد الرعوف ، "التعديل ألاتفاقي لنطاق الرقابة على أحكام التحكيم" ، ه مجلـــة

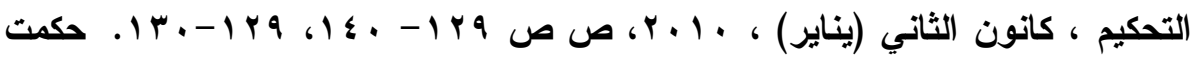

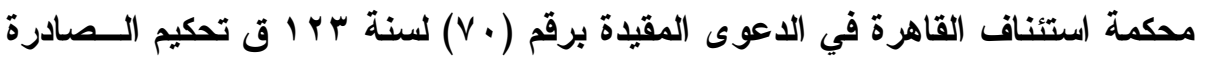

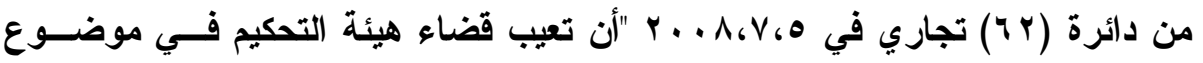

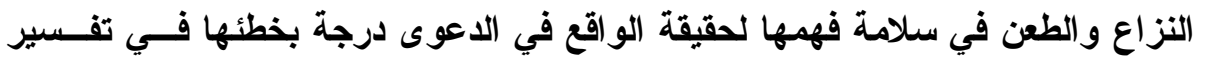
القانون وتطبيقه لا يتسع له نطاق دعوى البطلان ذلك لأن هذه الدعوى ليست طعناً عليه بالاستئناف فلا تتسع لإعادة النظر في موضوع النزاع وتعيب قضاء ذلك الحكم فيه و انه

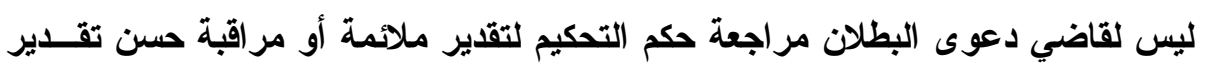

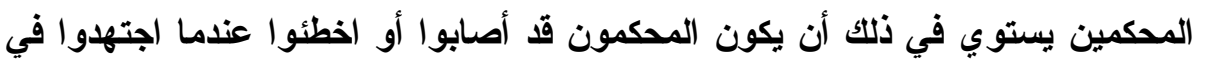
الحكم في التحكيم لأههم وحتى وأن أخطئوا فإن خطأهم لا ينهض سبياً لإبطال حكمه لأن

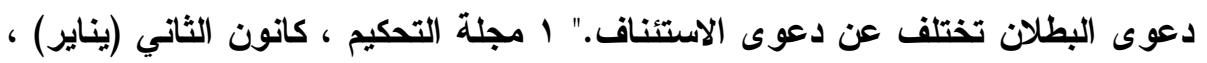
.010 . 1. 9 
الأحكام على حالات محدة على سبيل الحصر .(\$") وتبعاً لذلك فإن خطأ هيئة التحكيم في تطبيق القاتون أو الغلط في احتساب مدة التقادم أو خطأ المحكمين

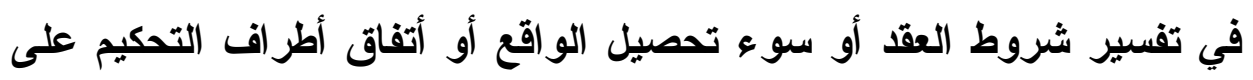

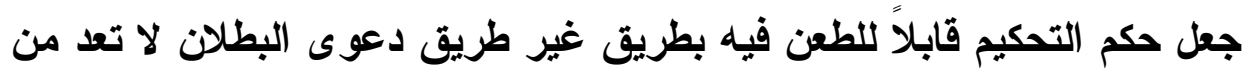
قبيل الأسباب التي تؤدي إلى بطلان حكم التحكيم. (70) ثانياً :المادة (qq) من اللايحة التنفيذية قضت المادة (بq) من اللائحة التنفيذية للنظام بأن "المحكمون يصدرون قراراتهم غير مقيدين بالإجر اءات النظامية عدا ما نص عليه في نظام التحكيم ولاحته التنقيذية. وتكون قرار اتهم بمقتضى أحكام الثريعة الإسلامية و الأظمة المرعية". هذه المادة فتحت الباب و اسعاً للقضاء لإبطال حكم التحكيم

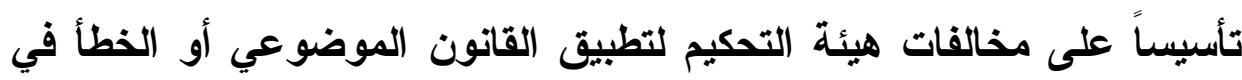
تفسيره أو تطبيقه لأن عبارة "الأظمة المرعية" تثمل القانون المبنه الموضوعي

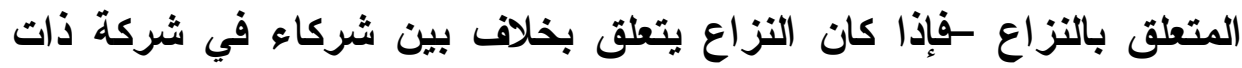

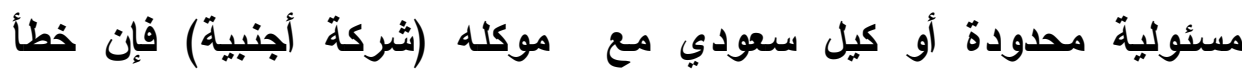
المحكمين في تطبيق أنظمة الثركات أو المحكمة التجارية أو الوكالات

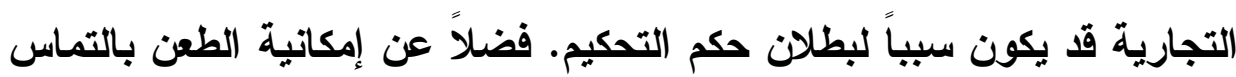
إعادة النظر مما يجعل الحكم غير محصن عند ثبوت غش أو صدور الحكم بناء

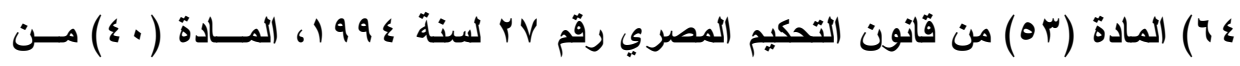

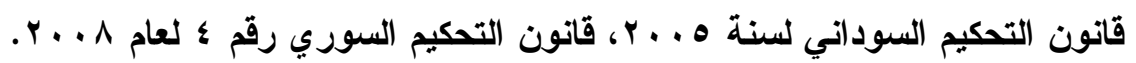

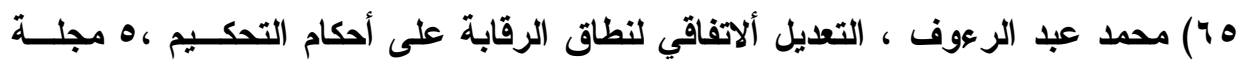

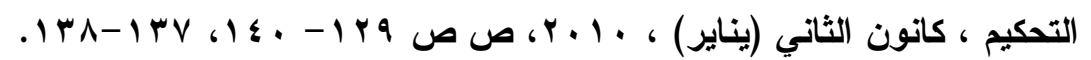


على مستندات أو شهادة قضي بتزويرها.("7) أن عدم تطبيق هيئة التحكيم للقانون السعودي المتفق على تطبيقه في اتفاق التحكيم من شأنه أن يؤدي إلى بطلان حكم التحكيم مما يحتم دخول المحكمة المختصة في موضوع الاعوى والتصدي للبت في الدعوى وفحص الوقائع والدفوع وإصدار الحكم الصحيح في ظل النظام الواجب التطبيق.(TV) كما أن مصطلح "الشريعة الإسلامية" مصطلح فضفاض وغير دقيق لاسيما وأن أحكام الثريعة الإسلامية لاز الت غير مقتنة وبالتالي فإن تفسير المصطلح بشكل واسع قد يفتح الباب على مصر اعيه لإجهاض عملية التحكيم برمتها ، لأن تعدد الآراء الفقهية في المسألة الواحدة بل أحياتاً اختلاف الحلول للمسألة الواحدة داخل المذهب الواحد تستدعي الاعوة إلى تقنين أحكام الثريعة الإسلامية في المعاملات المالية.(^^) ورغم ذللك فقد خول مشروع النظام الجديد أطراف التحكيم الحق في تعيين أية قواعد كقانون موضوعي واجب التطبيق على النزاع وتطبيق الثريعة الإسلامية والنظام العام بالمملكة فقط في حال عدم تعيين أطراف التحكيم قانون لحكم

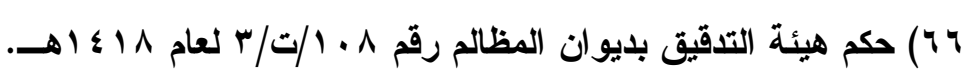

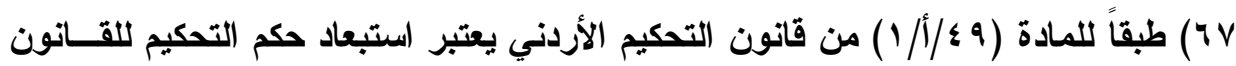
الأي أتفق الأطر اف على تطبيقه على موضوع النزاع من الحالات التي يجوز فيها قبول دعوى البطلان. ^^ا عبد الستار الخويلاي ، تعليق على تقرير فريق العمل المكلف من قبل لجنة التمويــل

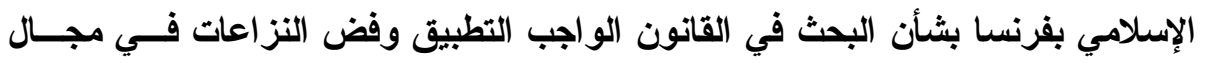

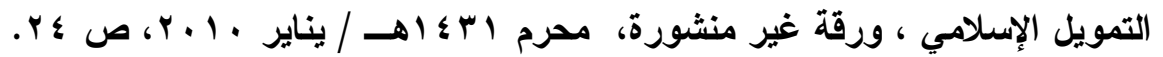

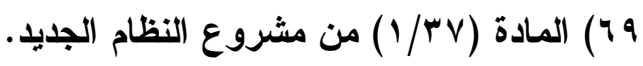


ثالثاً : الخلاف حول أتعاب المحكمين

أن نظام التحكيم ولائحته التفيذية خولا الخصوم حق الاعتراض على حكم التحكيم عند مخالفة هيئة التحكيم لنظام التحكيم ولائحته التنفيذية. ومن الحالات التي تبطل فيها المحكمة المختصة حكم تحكيم عندما يبت المحكمون في مسائل تخرج عن اختصاصهم بحكم النظام كالحكم بأتعاب المحكمين ومصاريف الاعوى عند غياب أتفاق بين الخصوم أو وجود خلاف حول تلك الأتعاب. وفقاً للمادة (Yr) من نظام التحكيم "تحدد أتعاب المحكمين باتفاق الخصوم ويودع ما لم يدفع منها لهم خلال خمسة أيام من صدور القرار باعثماد وثيقة التحكيم لاى الجهة المختصة أصلاً بنظر النزاع وتصرف خلا أسبوع من تاريخ صدور الأمر بتنفيذ الحكم." كما نصت المادة (YT) من ذات النظام على أنه "إذا لـ يوجد أتفاق حول أتعاب المحكمين وقام نزاع بشأنها تفصل فيه الجهة المختصة أصلاً بنظر النزاع ويكون حكمها في ذلك نهائياً." كما قضث المادة (0) من اللائحة التنفيذية على أنه "إذا أخفق كل من الخصمين في بعض الطلبات جاز الحكم بتقسيم الأتعاب بينهما على حسب ما تقدره الجهة المختصة أصلاً بنظر النزاع ، كما يجوز الحكم بها جميعاً على

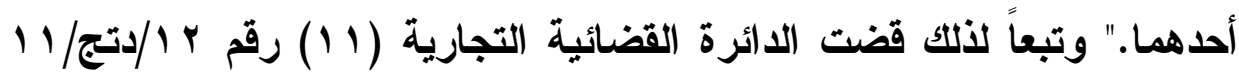

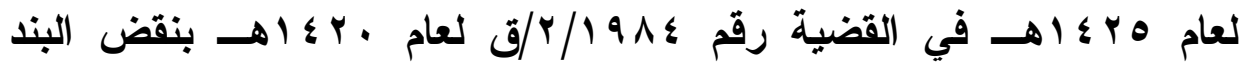
خامساً من قرار هيئة التحكيم المتعلق بأتعاب المحكمين ومصاريف الاعوى وقررت أنه عند وجود خلاف بين الطرفين حول الأتعاب فينعقد الاختصاص للادئرة - الجهة المختصة بالفصل في النزاع - تأسيساً على المادتين (Y (Y) 
د. ر نايف بن سلطان الشريف

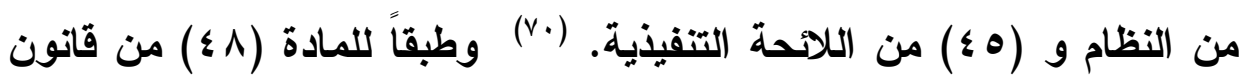
التحكيم الأردني فإن الطعن بتحديد الأتعاب لا يكون إلا بعد صدور الأحكام المنهية للخصومة لأن الغاية من اللجوء إلى التحكيم هو رغبة الخصوم في تجنب البطء في إجراءات التقاضي أمسام المحاكم.(vi)

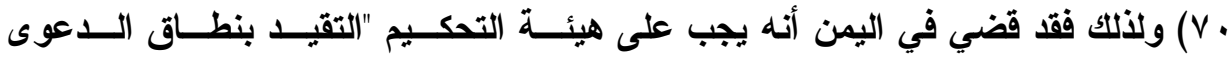

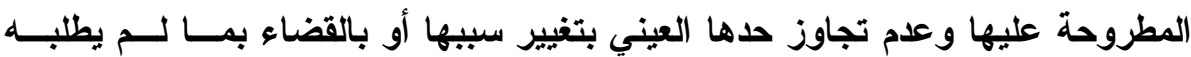
الخصوم أو بأكثر مما طلبوه ، لأن الفصل فيما يجاوز ذلك النطاق يعد فصلاً فيما لم ترفع

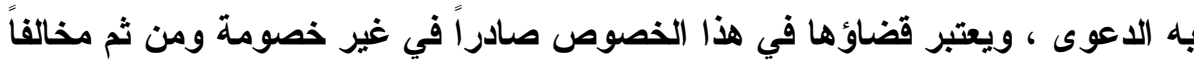

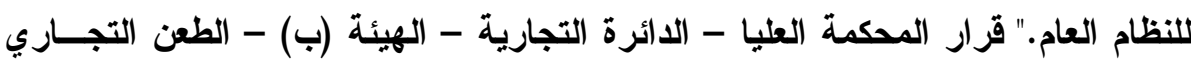

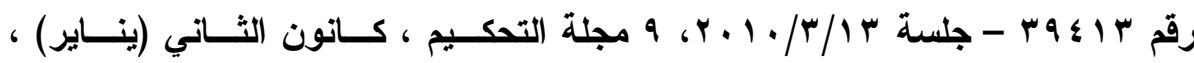

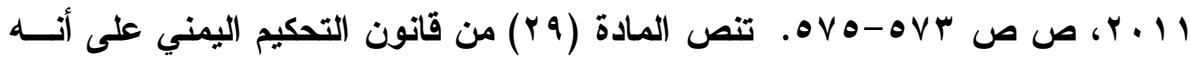

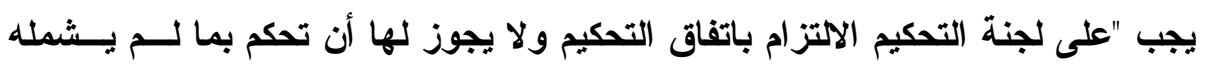
الاتفاق أو بما لم يطلبه طرفا التحكيم."

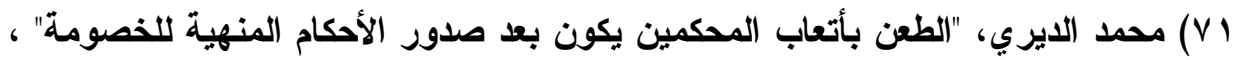

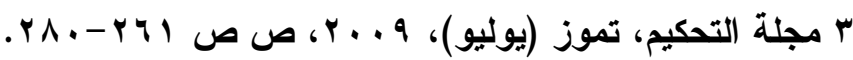


المبحث الثالث: تقييم العوائق في ظل مشروع النظام الجديد يناقش هذا المبحث المدى الذي وصل إليه مشروع النظام الجديد في معالجة العوائق التي أثتنمل عليها نظام التحكيم ولاتحته التنفيذية. ينقسم هذا المبحث إلى فرعين هما : تقييم العوائق واعتبارات الثريعة الإسلامية في ظل مشروع النظام. الفرع الأول : تقييم العوائق في ضوء مشروع النظام من التطورات التي استحدثها مشروع نظام التحكيم الجديد إلغاء ما يسمى بالرقابة السابقة على التحكيم إذ أن المشروع لم يشر من قريب أو أو بعيد

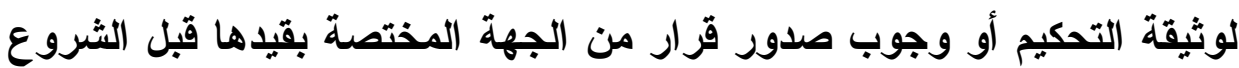

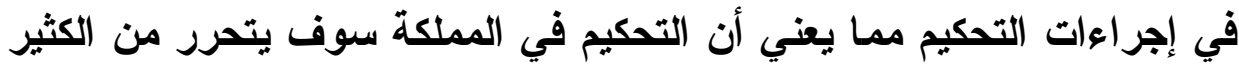
من القيود التي كانت تكبل وتأخر البدء في إجراءات التحكيم. ومن مظاهر التحرر التي جسدها المشروع الجديد التالي :

• جسيا مبدأ سلطان الإرادة فيما يتعلق باختيار المحكمين ومكان التحكيم

و القانون الواجب التطبيق ومراكز وهيئات التحكيم الدولية. (Vץ) • الاعتراف بالتحكيم التجاري الدولي لفض الخلافات التي تثتتمل على التى عنصر أجنبي. (vT) • توسيع مجال التحكيم ليثمل جميع المنازعات باستثناء مسائل الأحوال

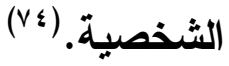

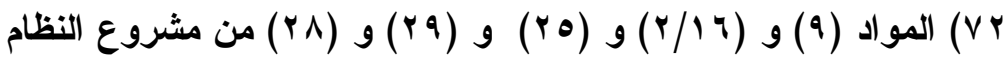

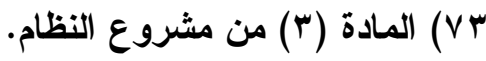

$$
\begin{aligned}
& \text { (المادة (1) (1) من مشروع النظام. } \\
& \text { مجلة البحوث القانونيت والإقتصاديت ؟ ؟ }
\end{aligned}
$$


د. ر نايف بن سلطان الشريف

• إخضاع تطبيق مشروع النظام لموافقته أحكام الاتفاقيات الاولية

$$
\text { المعمول بها في المملكة. (vo) }
$$

• علدم قبول الطعن في أحكام التحكيم بأي طريق من طرق الطعن. • المرونة والسرعة في البث في النزاع من خلال منع القضاء والخصوم من تعطيل إجراءات التحكيم عند مخالفة أحد الخصوم لشرط (التحكيم. (vv)

- منح شرط التحكيم استقلالية عن العقد وإعطاء المحكم اختصاص بالنظر في الافوع المتعلقة باختصاصه. (v^)

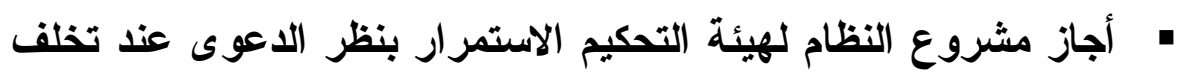
المدعى عليه من تقديم لاتحة جوابية بدفاعه.

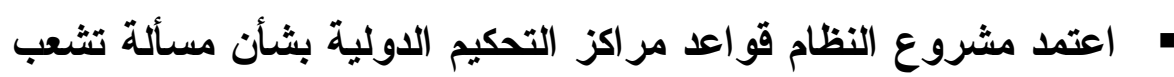
أراء هيئة التحكيم وعدم إمكانية الحصول على الأغلبية. • إلغاء أي قيود أو شروط تتعلق بأهلية المحكم فلا يشترط أن يكون

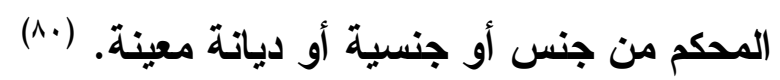
كذلك عالج مشروع النظام الجديد العوائق التي جسدتها المادتين (1/) و (9 (1) من النظام والمادة (q r) من اللائحة ويمكن إجمال التطور في النقاط

Do المادة (1) من مشروع النظام.

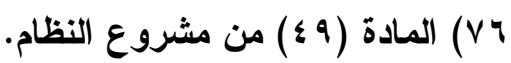

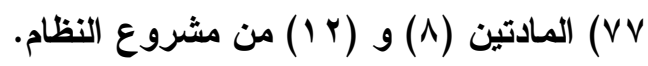

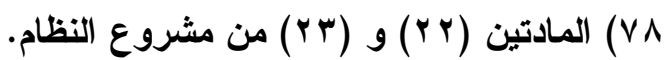

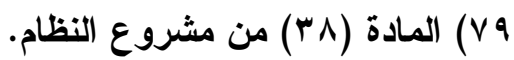

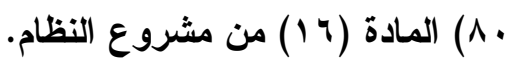




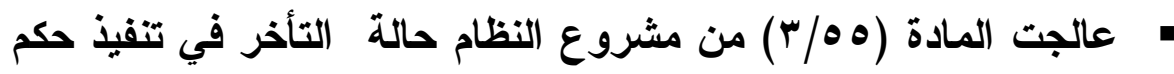
التحكيم فقد نصت على أنه "لا يجوز التظلم من الأمر الصادر بتنفيذ حكم التحكيم ، أما الأمر الصادر برفض التنفيذ فيجوز التظلم منه إلى الجهة المختصة خلال ثلاثين يوماً من تاريخ صدوره." كما أن المادة (Y/01) من ذات المشروع نصت على أنه "إذا قررت الجهة المختصة تأييد حكم التحكيم وجب عليها أن تأمر بتنفيذه ، ويكون قرارها في ذلك غير قابل للطعن بأي طريق من طرق الطعن، أما إذا قررت بطلان حكم التحكيم فيكون قرارها قابلاً للطعن خلا ثُلاثين يوماً من اليوم التالي للتبليغ." وق أوضحت الفقرة الثالثة من ذات المادة أن الاختصاص من بنظر دعوى البطلان في التحكيم التجاري الوطني ينعقد للارجة الثانية للجهة المختصة أصلاً بنظر النزاع في محل المدعى عليه ، ما لم بتفق لمقي الطرفان على غير ذلك. • حدث المادة (••) من مشروع النظام الجديد حالات دعوى بطلان حكم التحكيم في (V) حالات وردت على سبيل الحصر وتثثنابه تلك الحالات مع مثيلتها المنصوص عليها في قوانين التحكيم الحديثة واتفاقية نيويورك. (1)

1 ) تثمل هذه الحالات عدم وجود (تفاق تحكيم أو بطلاته أو قابليته للإبطال أو ســوطه

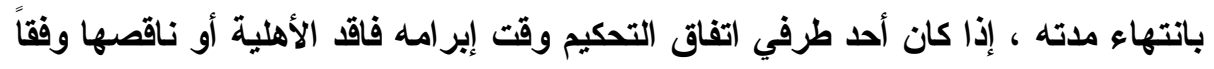
للنظام الذي يحكم أهليته ، تعذر أحد طرفي التحكيم تقديم دفاعه بسبب إنداء عدم إبلاغه إبلاغاً

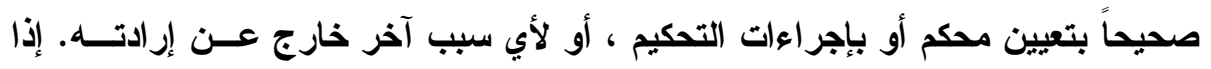

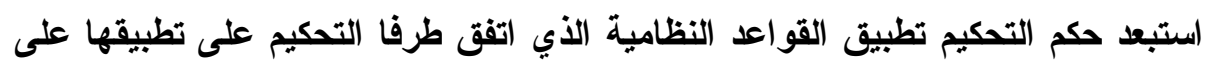

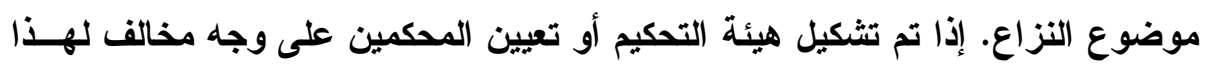

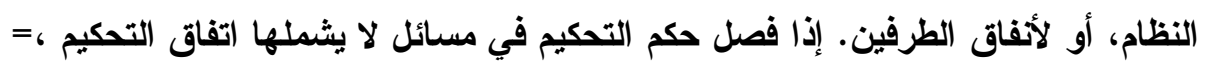


- أن المادة (rv) من مشروع النظام جسدت مبدأ سلطان الإرادة في تحديد القانون الواجب والتطبيق كما أتاحت لهيئة التحكيم حق تطبيق

الأعر اف والعادات التجارية المتعلقة بموضوع النزاع.

القرع الثاني : اعتبارات الثريعة الإسلامية في ظل مشروع النظام

وردت لفظة "الشريعة الإسلامية" مقرونة بلفظة "النظام العام" في

مشروع النظام الجديد في حالات ومواد محددة هي على النحو التالي :

- المادة ( • Y/O) كحالة من حالات بطلان حكم التحكيم إذا تضمن الحكم ما يخالف أحكام الشريعة الإسلامية و النظام العام بالمملكة.

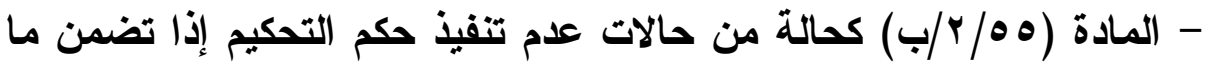
يخالف أحكام الشريعة الإسلامية و النظام العام بالمملكة ، و إذا أمكن تجزئة الحكم في ما يتضمنه من مخالفة ، جاز الأمر بتنفيذ الجزء الباقي غير المخالف.

- المادة (rv) كقاتون موضوعي واجب التطبيق إذا لم يعين أطر اف التحكيم أية قواعد موضوعية لتحكم النزاع .

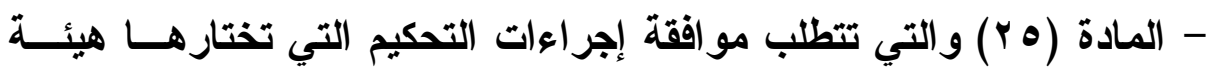
التحكيم أو طرفي التحكيم لأحكــام الــشريعة الإســلامية و النظــام العــام

= أو جاوز حدود هذا الاتفاق ، ومي ذلك إذا أمكن فصل أجزاء الحكم الخاصة بالمسائل

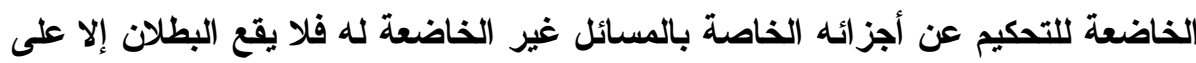

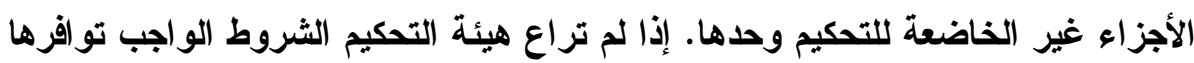

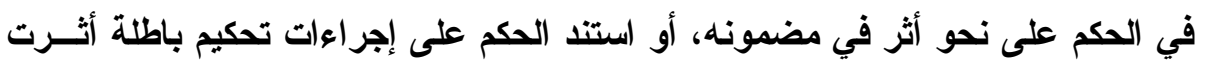


بالمملكة. ويقصد بذلك وجوب مراعاة هيئة التحكيم لقواعد الافاع واحترام

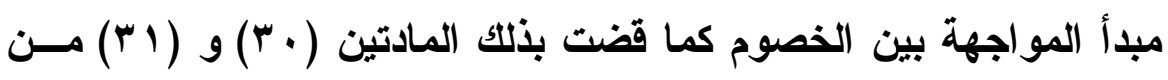
مشروع النظام الجديد.

- المادة (7) الواردة في سياق خضوع اتفاق التحكيم لأحكام عقد نمــوذجي أو اتفاقية دولية أو أية وثيقة أخرى حيث يجوز إعمال ما ورد في الوثيقة

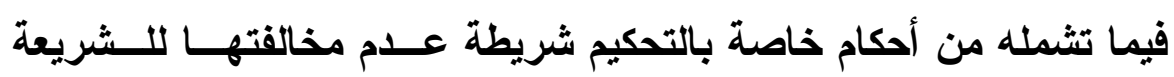
الإسلامية و النظام العام.

من المسائل التي يبطل فيها حكم التحكيم لمخالقته أحكام الثريعة الإسدلامية والنظام العام بالمملكة إذا اشتمل على فوائد ربوية أو تعويض عن

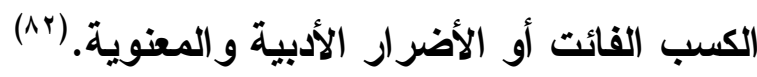
في حكم ديوان المظالم رقم · ب/د/ف/ • ا قضي بأن : " الائرة في سبيل إيضاح وجهة نظرها حول ذلك تفيد أنها تقف على أدلة وبراهين مستمدة من إجماع أو فتاوى صادرة من المجمعات الفقهية أو هيئة كبار العلماء تبين أن الربح الفائت والتعويض عن الضرر الأدبي أو هن المعنوي مخالف للشريعة الإسلامية لأن مثل هذا التعويض ياخل - والله أعلم

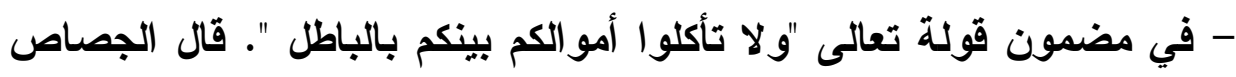
في تفسير هذه الآية قال أبن عباس والحسن - رضي الله عنهما- أن يأكله بغير عوض والتعويض عما يسمى بالربح الفائت والضرر الأدبي والمعنوي

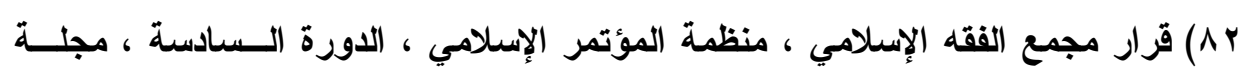

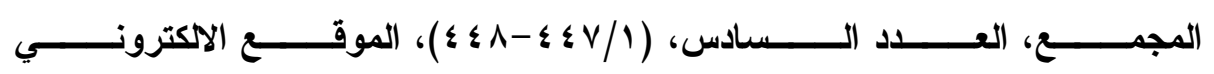
http ://www.fiqhacademy.org.sa/qarat/6-2.htm 
أخذ مال بلا عوض وقد قال القرافي في الفروق "أعلم أن القاعدة الشرعية بالأكثرية أنه لا يجوز أن يجمع العوضان لثخص وضل فاحل فإنانه يؤدي إلى أكل

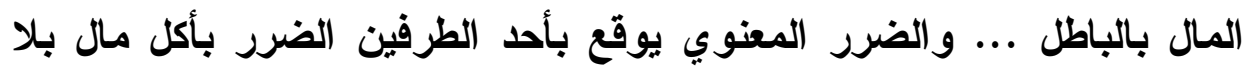

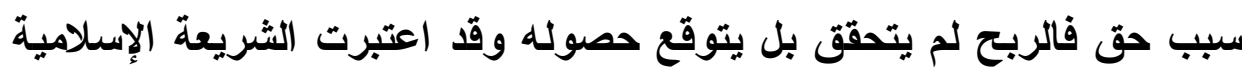

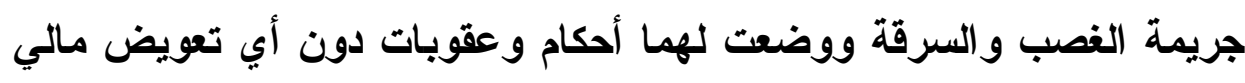

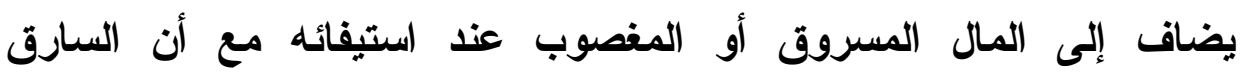
والغاصب قد فوتا على صاحب الحق الربح المتوقع فيما لو كان المال المسروق أو المغصوب في يده وهذا يدل على أن مبدأ الربح الفائت لا تقره

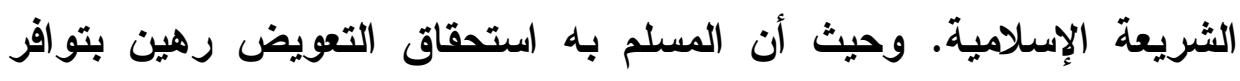

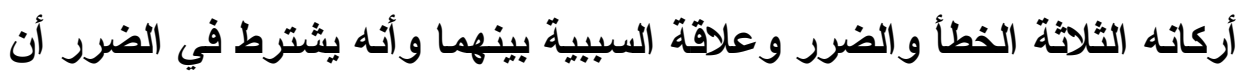
يكون محقق الوقوع وليس احتمالياً وحيث أن الضرر الذي تدعيه المدعية وتطلب التعويض عنه هو أمر مستقبلي غير محقق الوقوع مما يجعله احتمالياً

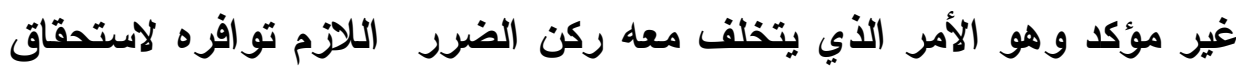

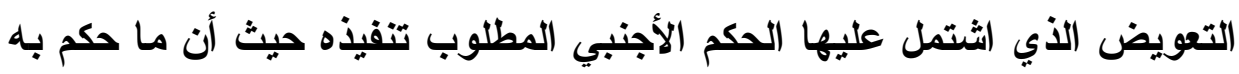
إنما هو أرباح كان يتوقع الحصول عليها من عمليات تجارية لم تتم ولا يخرج

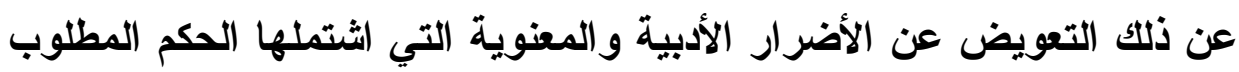

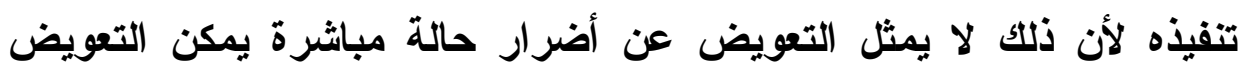

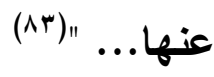

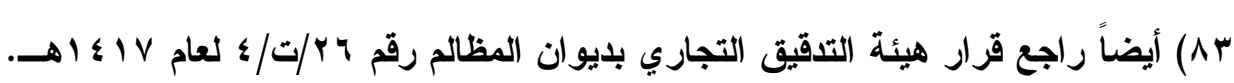

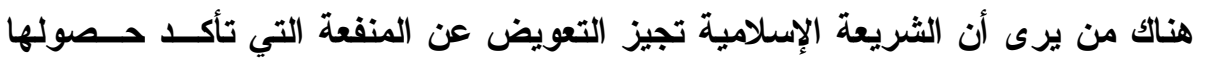

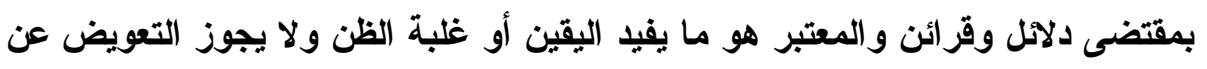

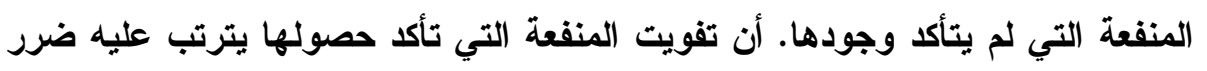

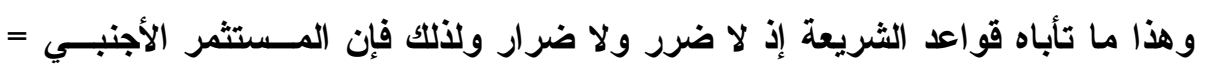


لقد أدى عدم تقنين أحكام الشريعة الإسلامية إلى استبعادها من قبل المحكمين في قضايا كثيرة كقضايا التحكيم بين الدول العربية وشركات الاستثمار الأجنبي في النصف الثاني من القرن المنصرم كما استبعدت أحكام الثريعة حديثاً في القضايا التي دخلتها البنوك في عقود التمويل الإسلامي رغم النص عليها كقانون واجب التطبيق.(^) وعليه فإنه يقترح على المشرع السعودي تعديل المادة (بq) من اللانحة التفقيذية للنظام بحيث يتم تقييا قرارات المحكمين بإجراعات التحكيم وقو اعد الشريعة الإسـلامية ذات الطبيعة الآمرة كما أن الوقت قد حان ألان لتقنين فقه المعاملات الإسلامية ووضع أطار عام وواضح لمفهوم النظام العام في الثريعة الإسلامية وتجميع القتاوى الصادرة من المجمعات الققهية وهيئة كبار العلماء والأحكام القضائية وفهرستها وترجمتها وتزويا

= يستطيع أن يطالب بتعويض على أساس القيمة السوقية في حال تعرض لنزع ملكيــة

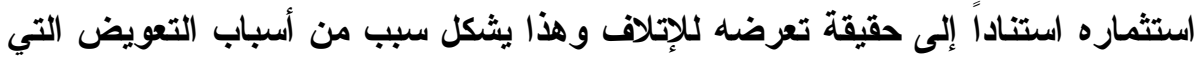

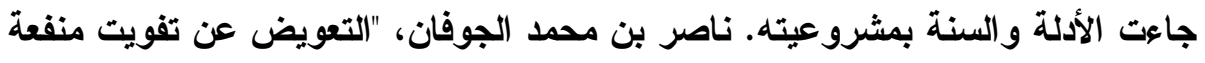

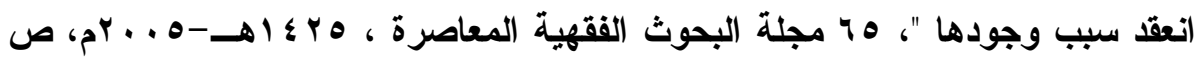

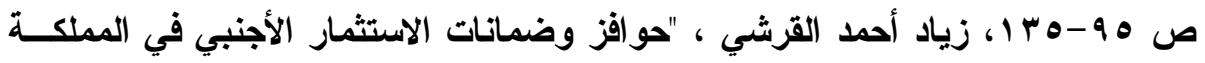
العربية السعودية: دراسة تحليلية لقانون وسياسات الاستثمار في ضوء ضون نظام الاستثمار و التزامات المملكة المنبثقة من اتفاقيات منظمة التجارة العالمية ذات الصلة"، - المجلد الأول V Vمجلة البحوث القانونية والاقتصادية ، كلية الحقوق - جامعة المنصورة، ابريل

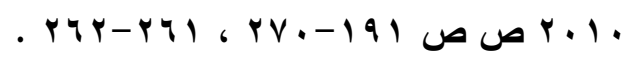

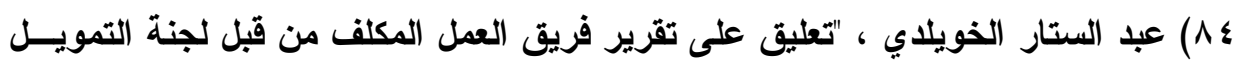

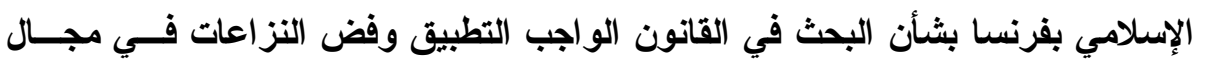

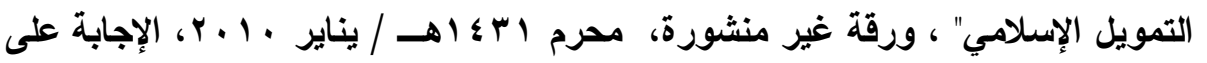

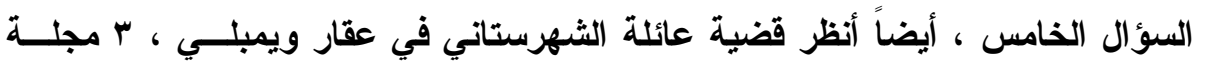

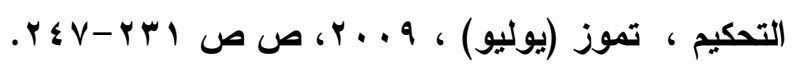


د. ر ايفـ بن سلطان الشريف

مر اكز التحكيم العربية والدولية بنست منها أو وضعها على موقع الكتروني بحيث يتاح للجميع الإطلاع عليها وتوحيد الأحكام القضائية من خلا "اختيار

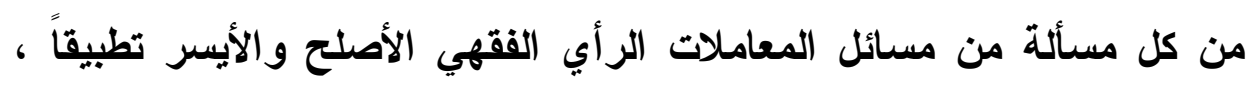
فتقنته السلطة المختصة حتى يكون وحده هو وحده الناقذ المفعول به في القضاء. فهذا التدبير النظامي في أحكام المعاملات بغية توحيد الحكم القضائي فيها هو واجب في طريق إقامة النظام وتحقيق العدل ، ولا يتنافى مع تعدد

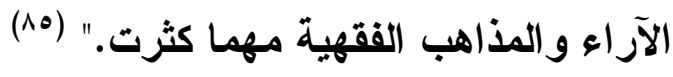

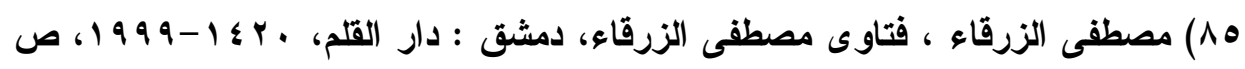

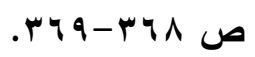

مجلت البحوث القانونيتوالإقتصاديت 1 م. 


\section{الخاتمة}

تهذف هذه الورقة إلى مناقثة أهم العوائق التي تواجه نظام التحكيم في

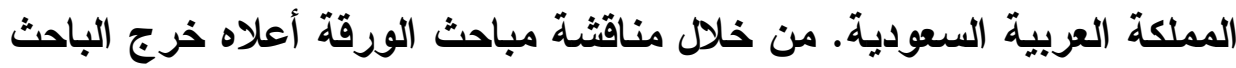
بالنتائج التالية : • أولا ، أن نظام التحكيم ولايحته التنفيذية لم يتضمنا أي أسباب يمكن من

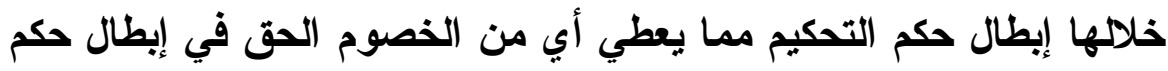

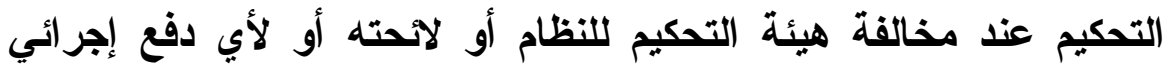

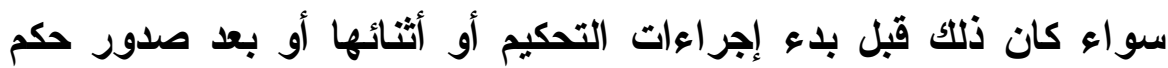

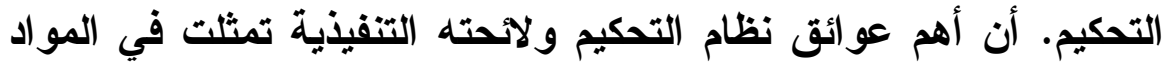

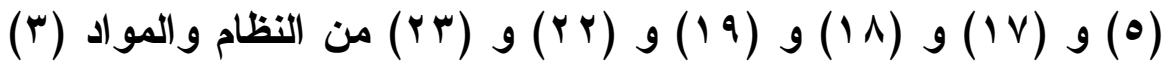

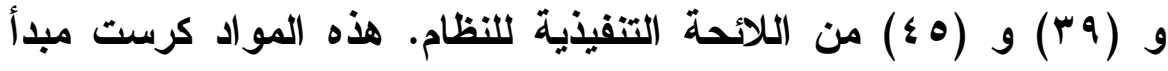
الرقابة القضائية السابقة على التحكيم من خلاه وجوب الهابه اعتماد وثيقة

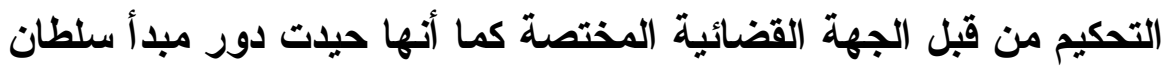
الإرادة في اختيار القانون والمكان واللغة وكذلك المحكمين غير المسلمين. أن وجود مثل هذه الرقابة وهذه القيود من شأنها أن تنفر التجار من وكن وكن اللجوء إلى التحكيم وتهميش أهميته كوسيلة سريعة لحسم المنازعات

$$
\text { التجارية. }
$$

" ثانياً ، أن نظام التحكيم ولاتحته التنفيذية قد اثتملا على ثغرات تنظيمية ومن ذلك عدم تحديد مهلة زمنية يتم خلالها إصدار هيئة التحكيم لقرار

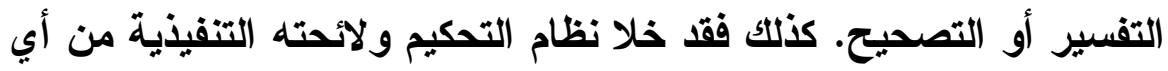


نص ينظم الحالات التي تغفل فيها هيئة التحكيم الطلبات المقدمة خلا إجراءات التحكيم.

ثالثاً ، أن أتفاق أطراف التحكيم على ميعاد لاتتهاء مهمة المحكمين في إصدار الحكم التحكيمي لا يعتبر من النظام العام وأن أجل الــــ (.9) يوماً المنصوص عليها في النظام لا يعتد به ، إلا في حالة عدم أتفاق المحكمين على أجل لإصدار الحكم كما تبين أن "أجل صدور حكم المحكمين" لا يعتبر من البيانات الإلزامية التي استلزمت المادة (0) من النظام توفرها في وثيقة التحكيم. " رابعاً، من الحالات التي يجوز فيها تمديد ميعاد صدور حكم التحكيم وفاة أحد الخصوم وزوال صفة المحمم وصدور قرار من هيئة التحكيم بتمديا أجل التحكيم والتمديا بناءً على أتفاق الخصوم فضلاً عن التمديد في من ولئه حالات تفسير وتصحيح حكم التحكيم وصدور حكم تحكيم إضافي في الحالة التي يثبت فيها إغفال هيئة التحكيم لأحد طلبات الخصوم. خامساً ، أن التوجه الأي سلكه القضاء السعودي عند نظره دعاوى بطلان أحكام التحكيم لا يتوافق والتطبيث والصحيح للنظام لأنه يخضع نهائية أحكام التحكيم لثلاث مراحل قضائية مما يتنافي من الحكمة وراء اللجوء إلى التحكيم ويجعل التحكيم أكثر مشقة وأكثر كلفة بالمقارنة مع اللجوء مئ من إلى القضاء العادي. سادساً ، أن نظام التحكيم أعطى الخصوم حق الاعتراض على أحكام التحكيم لمجرد مخالفة حكم التحكيم لنظام التحكيم ولاتحته التتفيذية حيث أتضح أن مخالفة هيئة التحكيم لطريقة أتعاب المحكمين من شأنها أن تمنح الجهة القضائية المختصة التصدي لموضوع النزاع في الجزئية 
المتعلقة بتقدير الأتعاب. كما أثبت الواقع العملي أن فشل هيئة التحكيم في تبريز حكمها عند طلب تقديم تفسير للحكم قد يؤدي في النهاية إلى بطلان حكم التحكيم وتصدي الجهة القضائية المختصة للبث في موضوع

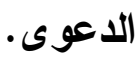
سابعاً ، من وجهة نظر مشروع النظام الجديد ، أن ضمان تنفيذ حكم التحكيم مرتبط بشكل رئيس بعدم مخالفته لأحكام الشريعة الإسلامية واعتبارات النظام العام. وعلى الرغم من عدم وضوح مصطلح أحكام الثريعة الإسلامية ومفهوم النظام العام بالمملكة بسبب عدم تقنين أحكام الشريعة الإسلامية فإن الاجتهاد القضائي أظهر عدم إمكانية تنفيذ أحكام التحكيم المشتملة على فوائد ربوية أو تعويض عن الكسب الفائت أو الإئ الأضرار الأدبية والمعنوية. أن أكبر إثكالية مستقبلية تواجه التحكيم في المملكة هي عدم إمكانية تنفيذ أحكام التحكيم استناداً إلى تطبيقات المحاكم لمفهوم الثريعة الإسلامية والنظام العام. لذلك فإن الباحث يرى أن الوقت قد حان لتقنين أحكام الشريعة الإسلامية في المملكة العربية السعودية لأن ذلك سوف يبرز محاسن الشريعة الجميلة ويساعد ذوي الثأن على معرفة الإطار العام لمفهوم النظام العام بالمملكة مما قد يسهل اختيار أحكام الشريعة كقاتون واجب التطبيق على النزاعات التجارية مما يؤدي في النهاية إلى تنفيذ أحكام التحكيم المحلية والأجنبية. ثامناً ، أن التوجه الأي سلكه المشرع السعودي من خلال مشروع نظام التحكيم الجديا - والأي جاء متوافقاً مع القانون المصري والقانون الأردني - سوف يخفف إلى حد كبير من العوائق التي تحد من اللجوء إلى التحكيم مما يساعد على جسر الهوة وتعزيز الثقة بين بيئة الأعمال 
المحلية وبيئة الأعمال الدولية وهذا بلوره سوف ينعكس إيجاباً على استقطاب المزيد من رؤوس الأموال الأجنبية إلى المملكة. أن منح الخصوم حق اختيار القانون الواجب التطبيق والمحكمين واللغة والمكان وتوسيع مجال التحكيم والاعتر اف بالاتفاقيات الدولية وحصر حالات بطلان أحكام التحكيم والاعتراف بالتحكيم التجاري الدولي واشتر اط عدم مخالفة أحكام مشروع النظام لأحكام الاتفاقيات الدولية تعتبر من أهم الإيجابيات التي جسدها مشروع النظام. تاسعاً، أن نجاح التحكيم في المملكة يتطلب الإسراع في إقرار مشروع نظام التحكيم الجديد وتهيئة المحكمين والقضاة وكذلك المحامين تجاه أفضل الممارسات والاجتهادات القضائية في الدول المتقدمة. كما أنه يتطلب إلغاء اللوائح والقرارات والتعاميم المتعلقة بالتحكيم والتي قد تخالف أحكام الاتفاقيات الاولية المصادق عليها من قبل حكومة المملكة العربية السعودية. فضلاً عن ذلك فإن الوقت قد حان لإنشاء مركز تحكيم تجاري دولي وذلك كي يتماثى مع ما تضمنه مشروع النظام الجديد من إمكانية خضوع النزاعات التجارية لأحكام المراكز والهيئات التحكيمية. 


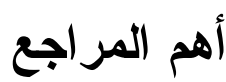

\section{المراجع الأولية}

• نظام التحكيم السعودي ، المرسوم الملكي رقم م/ ؟؛ ، تاريخ

$$
\text { اله }
$$

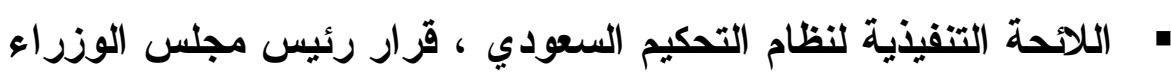

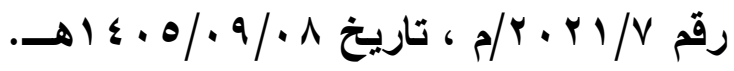

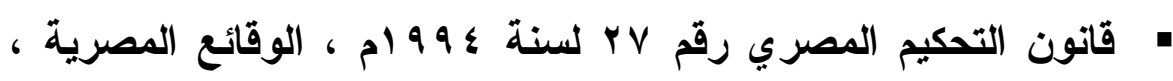

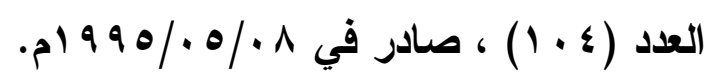

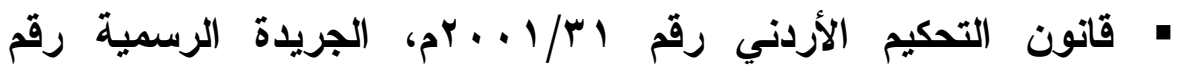

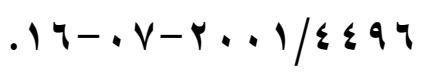

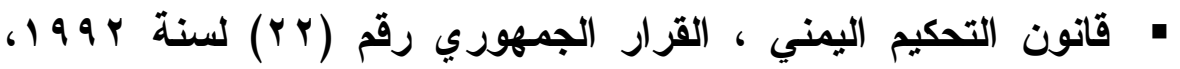

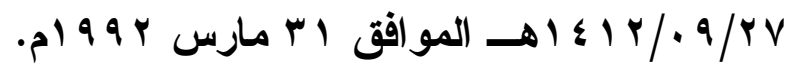

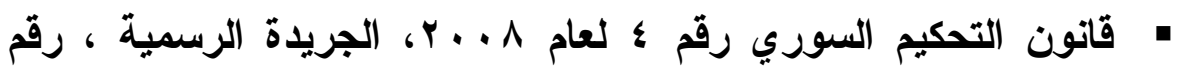

$$
10
$$

• قانون أصول المحاكمات المدنية اللبناني ، المرسوم الاشتراعي رقم

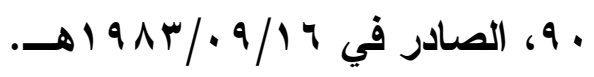

• القانون النموذجي للتحكيم ( اليونسترال )، لجنة الأمم المتحدة للقانون

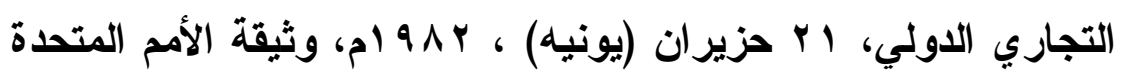

$$
\text { (أ) } \varepsilon \text { / IV }
$$


• أثجان فيصل شكري داود ، الطبيعة القانونية لحكم التحكيم وآثاره وطرق الطعن به : دراسة مقارنة ، أطروحة ماجستير غير منشورة ،

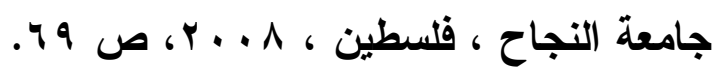
• تاج السر حامد ، "مدى جواز إنهاء إجراعات التحكيم عند تجاوز المدة في القانون السوداني"، $\wedge$ مجلة التحكيم ، تثرين الأول (أكتوبر)، .097، 091-09r ص ص صr. 1.

• خالد سعود الرشود ، "التحكيم التجاري في المملكة العربية السعودية"،

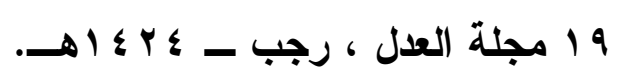
• رأت رشيد الميقاتي ، "Estoppel منع التناقض إضرار بالغير في الشريعة الإسلامية" ، ه مجلة التحكيم ، كانون الثاني (يناير) ،

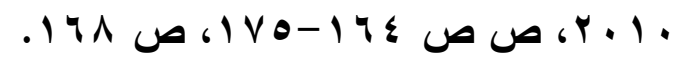
• رزق مقبل الريس ، ممارسة التحكيم ، ندوة الإتحاد الاولي للمحامين

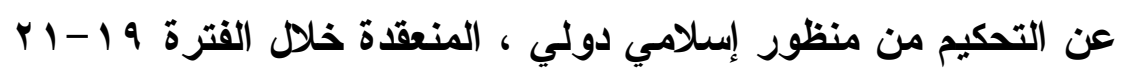

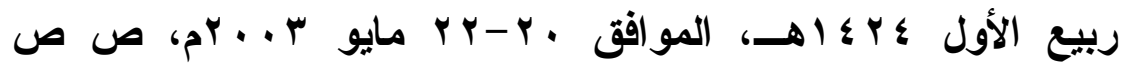

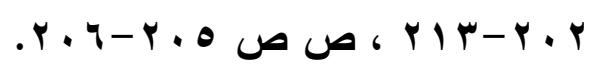

- ياد أحمد القزشي ، "حوافز وضمانات الاستثمار الأجنبي في المملكة العربية السعودية: دراسة تحليلية لقانون وسياسات الاستثمار في ضوء نظام الاستثمار والتزامات المملكة المنبثقة من اتفاقيات منظمة التجارة العالمية ذات الصلة"، - المجلد الأول V\&ملة البحوث 
القانونية والاقتصادية ، كلية الحقوق - جامعة المنصورة، ابريل

$$
\text { - rqr-rq1، rV.-191 מ ص P.1. }
$$

• عبد الستار الخويلاي ، "آليات الحد من المماطلة والتسويف في مجال التحكيم" ورقة عمل مقدمة في الملتقى السنوي الدولي الأول لمحكمي وخبراء المركز ، المركز الإسلامي الدولي للمصالحة والتحكيم، فندق

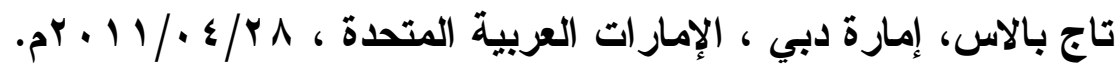
• عبد الستار الخويلاي ، تعليق على تقريز فريق العمل المكلف من قبل لجنة التمويل الإسلامي بفرنسا بشأن البحث في القاتون الواجب التطبيق وفض النزاعات في مجال التمويل الإسلامي ، ورقة غير

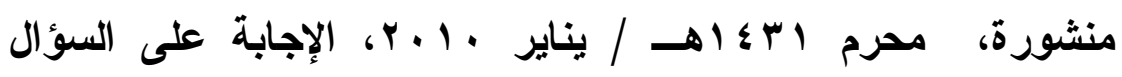

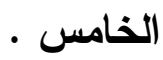

• عزمي أبو مغلي و أمجد حمدان الجهني ، "رقابة القضاء على حكم التحكيم في القانون الأردني" ، مجلة الشريعة والقانون ، ربيع الأول . YAV ، r r • عمر مشهور حديثة الجازي ، 9،، ـ 1 مجلة نقابة المحامين، أيلول -

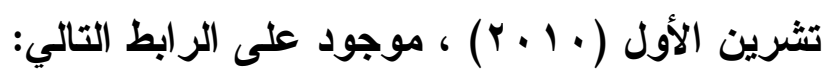
http://www.jcdr.com/pdf/3-ar.pdf - محمد البجاد ، "التحكيم وفوائده ومعوقاته" ، r r مجلة تجارة

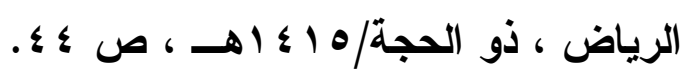
• محد البجاد ، التحكيم في المملكة العربية السعودية، الرياض: مركز

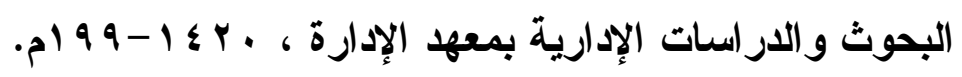


د. ر ائف بن سلطان الشريف

• محمد الايري، "الطعن بأتعاب المحكمين يكون بعد صدور الأحكام

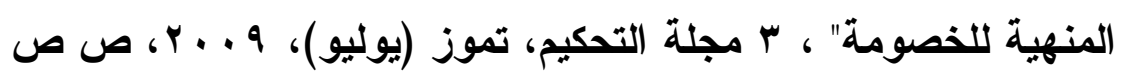

$$
. r \wedge \cdot-r q 1
$$

• محد الهوشان ، موقف القضاء التجاري السعودي من إعمال شرط

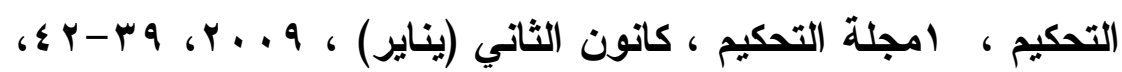
$. \varepsilon 1-\varepsilon$.

• محمد صلاح الدين عبد الوهاب ، "إنهاء إجراءات التحكيم لتجاوز المدة بين سلطان الإرادة وأحكام القانون"، ^ مجلة التحكيم، تشرين الأول

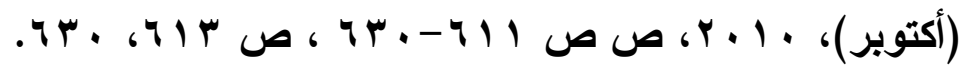

• محمد عبد الرعوف ، التعديل الاتفاقي لنطاق الرقابة على أحكام

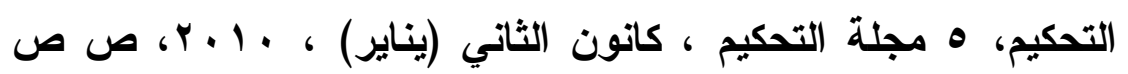

$$
.1 r \wedge-1 r v 61 r \cdot-1 r q, 1 \leq \cdot-1 r q
$$

• مصطفى الزرقاء ، فتاوى مصطفى الزرقاء، دمشق : دار القلم،

$$
\text { .r }
$$

• منصور بن حمد المالك، ندوة الإتحاد الاولي للمحامين عن التحكيم من

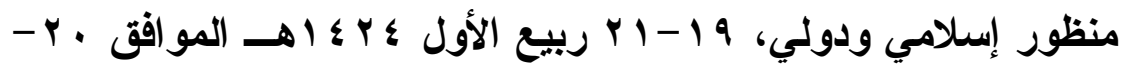

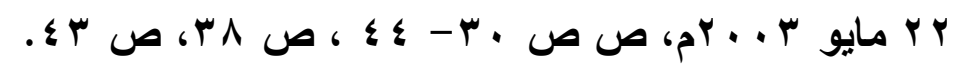

| ناصر بن محمد الجوفان، "(التعويض عن تفويت منفعة انعق سبب وجودها "، هو مجلة البحوث الفقهية المعاصرة ، هب ؛ اهـ-

$$
\text { ا }
$$


د. ر ائف بن سلطان الشريف

• نايف سلطان الشريف، "البيئة التجارية في المملكة تتطلب إصدار نظام تحكيم مستقل"، ه

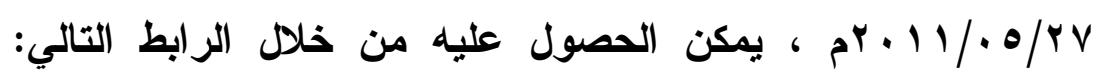
http://al-madina.com/node/306003

- نجيب أحمد عبد الله ثابت الجبلي ، التحكيم في القوانين العربية : در اسة مقارنة في الفقه الإسدلامي والأظظمة الوضعية، المكتب الجامعي

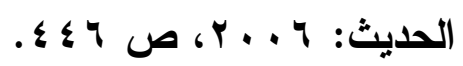

• يعقوب يوسف صرخوه، "ثروط صحة التحكيم في التشريع الكويتي مقارنة بما ورد في اتفاقيات التحكيم الصادرة في رحاب الأمم المتحدة"،

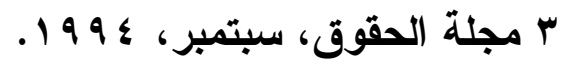
القزار ات و الأحكام القضائية

• رزار مجمع الفقه الإسدلامي ، منظمة المؤتمر الإسدلامي ، الاورة

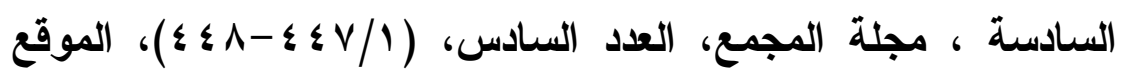
http ://www.fiqhacademy.org.sa/qarat/6-2.htm الاكتروني

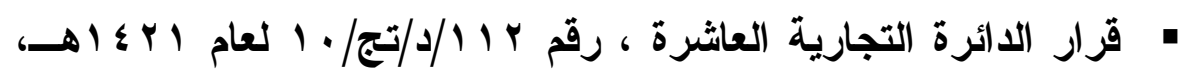
ديوان المظالم بمنطقة مكة المكرمة.

• قرار الدائرة التجارية التاسعة بليوان المظالم، الصادر في

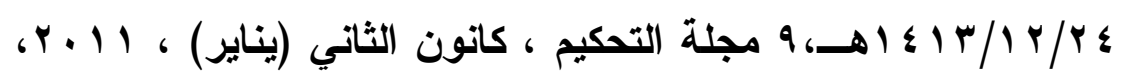

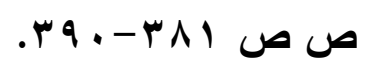

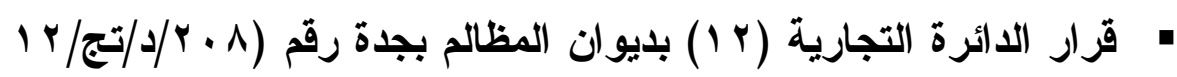

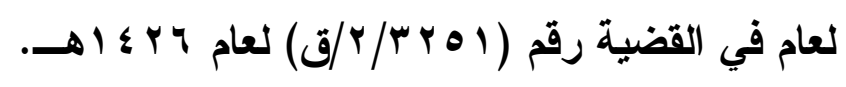

مجلت البحوث القانونيت والإقتصاديت . 1. 


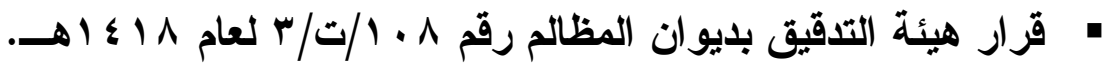
• قرار الغزفة التجارية بالمغرب ، المجلس الأعلى (محكمة النقض) ،

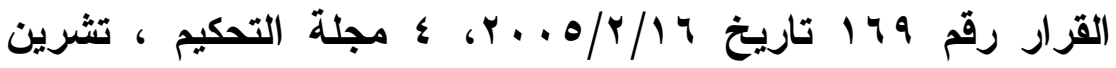

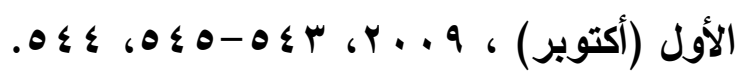

• قرار رئيس الغرفة الابتدائية الأولى في بيروت رقم ر/rا في

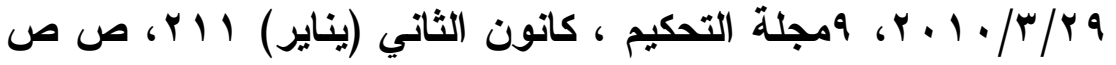

$$
. \varepsilon \vee \vee-\varepsilon \vee ५
$$

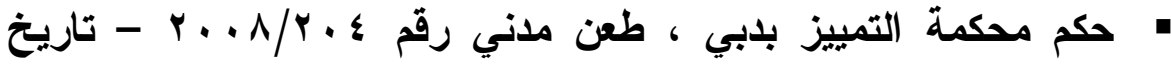

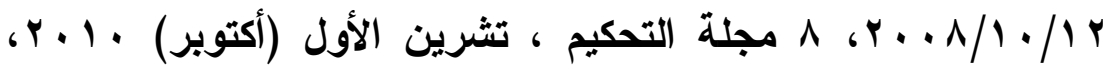

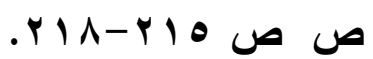

• حكم محكمة التمييز البحرينية - الطعن رقم بr ـ لسنة r . . r جلسة

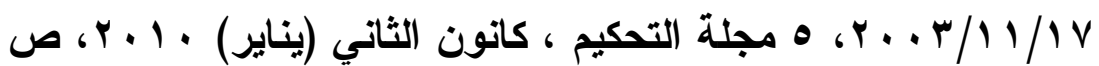

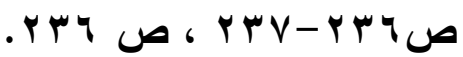

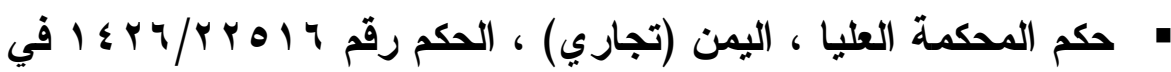

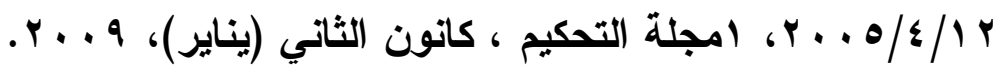
• حكم محكمة استئناف القاهرة ، الدائرة السابعة التجارية ، الدعوى رقم

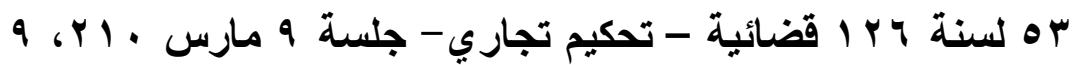

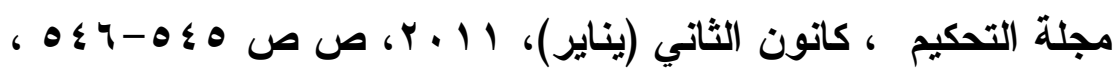
$.0 \leq 7$ 
• حكم محكمة استئناف القاهرة في الدعوى المقيدة برقم ( • ل لسنة

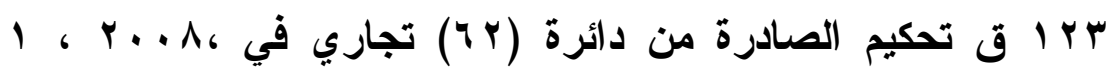

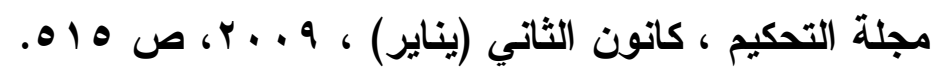
• كم محكمة النقض المصرية، الدائرة المدنية التجارية، الطعنين رقم

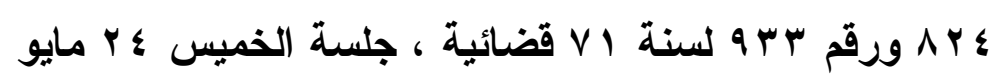

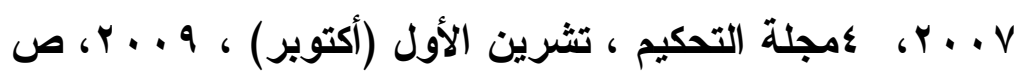
ص. D

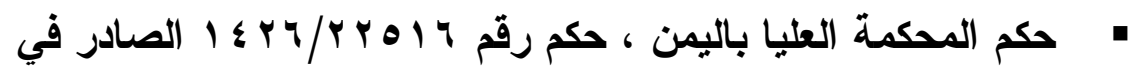

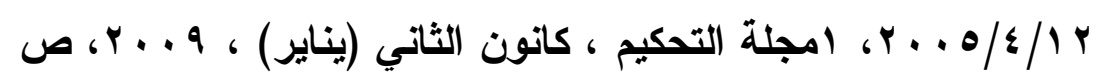
$. \Delta \wedge r-\bullet \wedge \cdot \Delta$

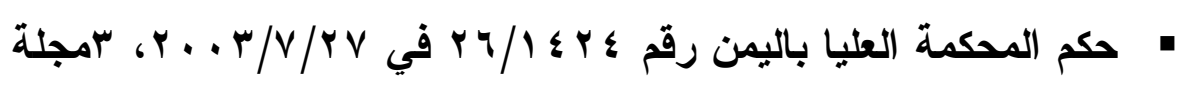

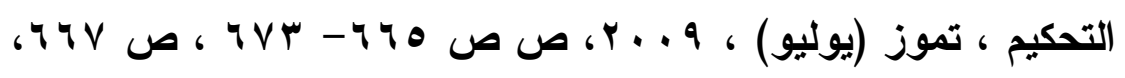
. IVT

- حكم المحكمة العليا - الائرة التجارية - الهيئة (ب) - الطعن التجاري

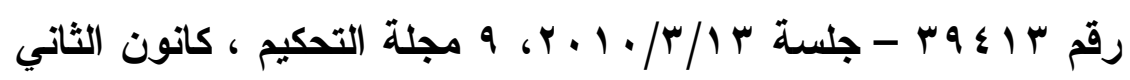

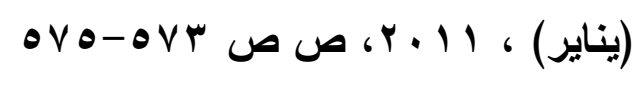

• قضية عائلة الشهرستاني في عقار ويمبلي ، ب مجلة التحكيم ، تموز

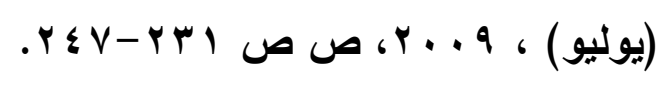

